\title{
Working
}

Paper 


\section{Quantifying Structural Subsidy Values for Systemically Important Financial Institutions}

Kenichi Ueda and Beatrice Weder di Mauro 
This page intentionally left blank

CInternational Monetary Fund. Not for Redistribution 


\title{
IMF Working Paper
}

Research Department

\section{Quantifying Structural Subsidy Values for Systemically Important Financial Institutions}

\author{
Prepared by Kenichi Ueda and Beatrice Weder di Mauro ${ }^{1}$
}

Authorized for distribution by Stijn Claessens

May 2012

\section{This Working Paper should not be reported as representing the views of the IMF.}

The views expressed in this Working Paper are those of the author(s) and do not necessarily represent those of the IMF or IMF policy. Working Papers describe research in progress by the author(s) and are published to elicit comments and to further debate.

\begin{abstract}
Claimants to SIFIs receive transfers when governments are forced into bailouts. Ex ante, the bailout expectation lowers daily funding costs. This funding cost differential reflects both the structural level of the government support and the time-varying market valuation for such a support. With large worldwide sample of banks, we estimate the structural subsidy values by exploiting expectations of state support embedded in credit ratings and by using long-run average value of rating bonus. It was already sizable, 60 basis points, as of the end-2007, before the crisis. It increased to 80 basis points by the end-2009.
\end{abstract}

JEL Classification Numbers: G21; G28; H12

Keywords: Systemically important financial institutions; bank funding subsidy; bank bailout Author’s E-Mail Address: KUeda@imf.org; beatrice.weder@uni-mainz.de

\footnotetext{
${ }^{1}$ For helpful comments, we would like to thank Stijn Claessens, Dale Gray, Jörg Rocholl, and the participants at an IMF seminar, at a conference for the Deutsche Bundesbank (June 9-10, 2011, Berlin), and at the Annual Conference of the German Economic Association (September 5, 2011). We are very grateful to Hyeon Ji Lee for excellent research assistance. This paper was written while Weder di Mauro was a resident scholar at the IMF. The views expressed in this paper are those of the authors and should not be attributed to the International Monetary Fund, its Executive Board, or its management.
} 


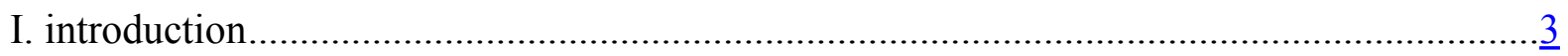

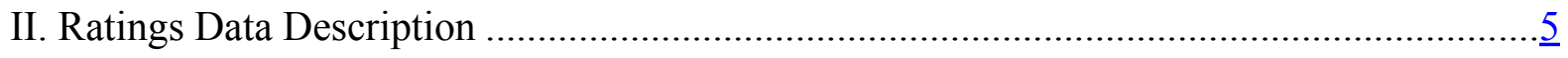

III. Estimating the Impact of Government Support on Overall Ratings ..................................

A. Benchmark Estimation ......................................................................................

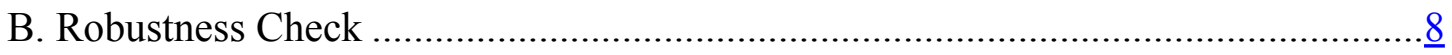

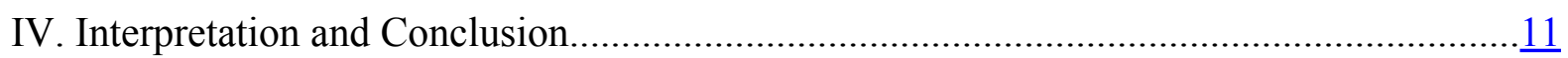

Tables

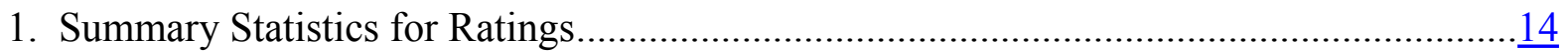

2. Summary Statistics for Support Ratings for Selected Countries .......................................14

3. OLS Regression Results of Support Rating on Bank Size ............................................15

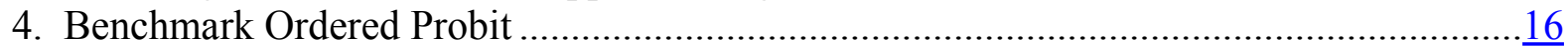

5. Dropping Samples with NF in Support Floor Rating ……..........................................

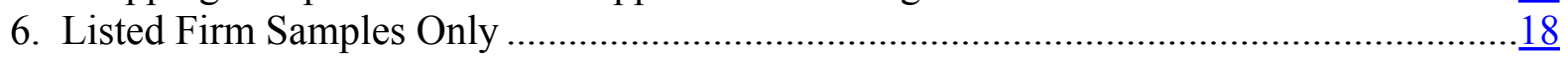

7. Using Firm Balance Sheet Information for Listed Firms ...............................................19

8. Summary Table: Effect of a One-Notch Government Support Increase ............................

9. Summary Table: Estimated Average Government Support in Long-Term Ratings.............

Figures

1. Distribution of Support Ratings and of Support Floor Ratings .........................................

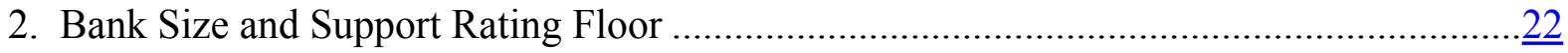

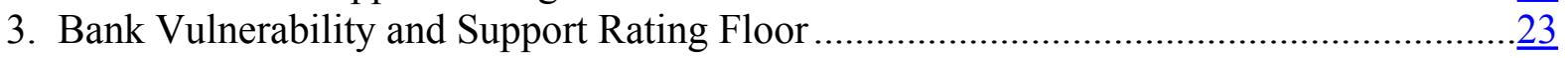

Appendixes

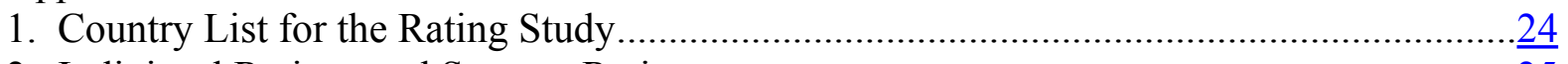

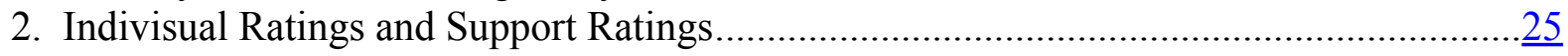

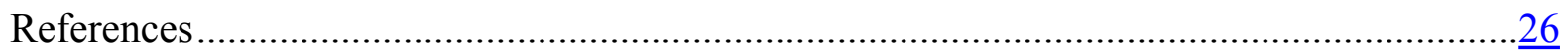




\section{INTRODUCTION}

One of the most troubling legacies of the financial crisis is the problem of "too-systemically important-to-fail" financial institutions. Public policy had long recognized the dangers that systemically relevant institutions pose for the financial system and for public sector balance sheets, but in practice, this problem was not deemed to be extremely pressing. It was mainly dealt with by creating some uncertainty (constructive ambiguity) about the willingness of government intervention in a crisis.

The recent crisis since 2008 provided a real-life test of the willingness to intervene. After governments have proven their willingness to extended large-scale support, constructive ambiguity has given way to near certainty that sufficiently large or complex institutions will not be allowed to fail. Thus, countries have emerged from the financial crisis with an even larger problem: Many banks are larger than before and so are implicit government guarantees. In addition, it also becomes clear that these guarantees are not limited to large institutions. In Europe, smaller institutions with a high degree of interconnectedness, complexity, or political importance were also considered too important to fail.

The international community is addressing the problem of SIFIs with a two-pronged approach. ${ }^{2}$ On the one hand, the probability of SIFIs failure is to be reduced through higher capital buffers and tighter supervision. ${ }^{3}$ On the other hand, SIFIs are to be made more "resolvable" by subjecting them to special resolutions regimes (e.g., living wills and CoCos). A number of countries have already adopted special regimes at the national level or are in the process of doing so. However, it remains highly doubtful whether these regimes would be operable across borders. ${ }^{4}$ This regulatory coordination failure implies that creditors of SIFIs continue to enjoy implicit guarantees.

Subsidies arising from size and complexity create incentives for banks to become even larger and more complex. Hence, eliminating the value of the implicit structural subsidy to SIFIs should contribute to reducing both the probability and magnitude of (future) financial crises. Market participants tend to dismiss these concerns by stating that these effects may be there in theory but are very small in practice. Therefore, it requires an empirical study to quantify the value of state subsidies to SIFIs. This is the aim of this paper.

How can we estimate the value of structural state guarantees? As institutions with state backing are safer, investors ask for a lower risk premium, taking into account the expected future transfers from the government. Therefore, before crisis, the expected value of state guarantees is the difference in funding costs between a privileged bank and a non-privileged bank. A caveat of this reasoning is that this distortion might affect the competitive behaviors and the market shares

\footnotetext{
${ }^{2}$ See FSB (2010a and b)

3 An alternative approach would be to internalize systemic risk externalities with a levy (Pigouvian taxation), as suggested inter alia by Acharya et.al. (2009), Doluca et. Al. (2010), FSB (2010a), IMF (2010a), Kocherlakota (2010), and Perotti and Suarez (2010).

${ }^{4}$ See, for example, Claessens et.al. (2010).
} 
of both the subsidized and the non-subsidized financial institutions. Therefore, the difference in observed funding costs may include indirect effects in addition to the direct subsidy for SIFIs. ${ }^{5}$

We estimate the value of the structural subsidy using expectations of government support embedded in credit ratings. Overall ratings (and funding costs) of financial institutions have two constituent parts: their own financial strength and the expected amount of external support. External support can be provided by a parent company or by the government. Some rating agencies (e.g., Fitch) provide regular quantitative estimates of the probability that a particular financial institution would receive external support in case of crisis. We isolate the government support component and provide estimates of the value of this subsidy as of end-2007 and end-2009.

We find that the structural subsidy value is already sizable as of end-2007 and increased substantially by the end-2009, after key governments confirmed bailout expectations. On average, banks in major countries enjoyed credit rating bonuses of 1.8-3.4 at the end-2007 and 2.5-4.2 at the end-2009. This can be translated into a funding cost advantage roughly $60 \mathrm{bp}$ and $80 \mathrm{bp}$, respectively.

The use of ratings might be considered problematic because rating agencies have been known to make mistakes in their judgments. For instance, they have been under heavy criticism for overrating structured products in the wake of the financial crisis. However, whether rating agencies assess default risks correctly is not important for the question at hand. All that matters is that markets use ratings in pricing debt instruments and those ratings influence funding costs. This has been the case. ${ }^{6}$ Therefore, we can use the difference in overall credit ratings of banks as a proxy for the difference in their structural funding costs. Our empirical approach is to extract the value of structural subsidy from support ratings, while taking into account bank-specific factors that determine banks' own financial strength as well as country-specific factors that determine governments' fiscal ability to offer support.

A related study by Baker and McArthur (2009) obtains a somewhat lower value of the subsidy, ranging from $9 \mathrm{bp}$ to $49 \mathrm{bp}$. However, the difference in results can be explained by different empirical strategies: Baker and McArthur use the change in the difference in funding costs between small and large US banks before and after TARP. With this technique, they identify the change in the value of the SIFIs subsidy, which is assumed to be created by the government bailout intervention. However, they cannot account for a possible level of bailout expectations that may have been embedded in prices long before the financial crisis. This ignorance is a drawback of all studies that use bailout events to quantify the value of subsidy: They can be quite precise in estimating the change in the subsidy due to a particular intervention but they will

\footnotetext{
${ }^{5}$ The effect on competitive behavior and risk taking of non-subsidized firms may be even larger than the one on subsidized firms. See Gropp, Hakenes, and Schnabel (2011).

${ }^{6}$ See, for example, Morgan and Stiroh (2006) and Resti and Sironi (2005) for studies of how ratings determine spreads of European and U.S. banks.
} 
underestimate the total level of the subsidy if the support is positive even in tranquil times. ${ }^{7}$ In other words, they cannot establish the value of funding cost advantages accruing from expected state support even before the crisis. ${ }^{8}$

This characteristic is the distinct advantage of the rating approach. It allows us to estimate not only the change of the subsidy during the crisis but also the total value of the subsidy before the crisis. As far as we are aware, there are only a few previous papers which use ratings. Soussa (2000), Rime (2005), and Morgan and Stiroh (2005) used similar approaches to back out the value of the subsidy. However, our study is more comprehensive by including a larger set of banks and countries and also by covering the 2008 financial crisis.

Assuming that the equity values are not so much affected by bailouts but the debt values are, the time-varying estimates of the government guarantees can be calculated using a standard option pricing theory. ${ }^{9}$ However, the funding cost advantage in crisis reflects two components: first, the structural government support and, second, a larger risk premium due to market turmoil. If we calculate the value of one rating bonus only in crisis times, the value of bonus would be larger because of the latter effect. However, when designing a corrective levy, the value of the government support should not be affected by these short-run market movements. For this reason, the long-run average value of one rating bonus - used here to calculate the total value of the structural government support - should be more suitable as a basis for a collective levy than real-time estimates for the market value of the government guarantees.

The paper is organized as follows. Section II provides details on ratings definitions, methodology, and some descriptive statistics. Section III contains our benchmark estimates and a series of robustness checks. Section IV concludes.

\section{RATINGS DATA DESCRIPTION}

To study the value of state support embedded in ratings, we collect a data set of all banks for which Fitch provides the necessary ratings data. The advantage of Fitch is that it publishes

\footnotetext{
${ }^{7}$ Moreover, as an event study, Baker and McArthur's result might not be so precise. Because they use only quarterly averages of funding rates, their estimates are likely to be contaminated by polices and bank-specific changes within a quarter.

${ }^{8}$ Nevertheless, event studies can be instructive. In a companion paper, Ueda and Weder di Mauro (2010), we also use an event study approach, which is similar in spirit to Baker and McArthur, to single out at the effect of individual bailout events. Our event study methodology, however, differs from Baker and McArthur by focusing on a small window, thus eliminating possible contamination with other policy changes. We also control for bankspecific factors that may affect funding differences, such as differences in a bank's own financial strength. This could influence results, since large banks may have been hurt more from the sharp fall in the value of complex financial instruments (i.e., the competitive distortion might have become wider). Another paper using the event study methodology is Veronesi and Zingales (2009), who analyze the effects of the Paulson Plan (10/13/2009). Gandhi and Lustig (2010) also extract small vs. large bank differences in U.S. stock prices over time, but do not use an event study. Similarly, from stock price movements, Kaplan-Appio (2002) estimated the option value of government guarantees to Thai banks prior to Asian Crisis of 1997.

${ }^{9}$ See, for example, Gray and Jobst (2010) for methodology and IMF (2010b) and Moody’s (2011) for application to large U.S. banks.
} 
ratings for several different dimensions of the creditworthiness of issuers. In particular, they distinguish between overall credit ratings and ratings with and without support from government or from parent banks. This allows us to isolate the effect of state support on a bank's overall rating.

The best known rating category is the overall rating, which reflects Fitch's views of the issuers' overall vulnerability to default. The overall rating is based on the issuer's capacity for payment of its financial commitments and its capacity to withstand adverse business and economic events. ${ }^{10}$ As the primary variable, we use long-term credit ratings, which are graded from AAA to $\mathrm{D}$. We assign 1 to 16 numeric values, with 16 denoting the highest rating (AAA).

Individual ratings are designed to assess a bank's financial strength on a stand-alone basis. The rating scale runs from $\mathrm{A}$ to $\mathrm{E}$, with gradations like $\mathrm{A} / \mathrm{B}$ or $\mathrm{B} / \mathrm{C}$. For instance, $\mathrm{D}$ D is assigned to a bank that has considerable weaknesses of internal or external origin, including concerns on balance sheet integrity, franchise, management, profitability, and so forth. A bank with an F rating is either in default or would have defaulted if it did not receive external support (see Appendix Table 2). We assign 1 to 11 numeric values, with 11 denoting the highest rating (A).

The Support Rating that Fitch provides runs from 1 to 5, with 1 indicating an extremely high probability of external support and 5 a weak probability of external support. However, the supporters can be either a government or a parent bank. We use flipped values for regressions (see Appendix Table 2).

Fitch also provides a rating for a government's ability to provide support: the Support Rating Floor. This is given whenever the Support Rating is based on potential sovereign support, and the absence of a Support Rating Floor means that external support is expected from a parent bank. We use this information to construct a dummy variable for the support from parent banks (Parent). The Support Rating Floor is expressed on the 'AAA' long-term scale and indicates the level below which the agency would not expect the rating to fall. Again, we assign the numeric values 1-16.

In addition to the bank level ratings, we also use sovereign ratings for two purposes. First, they serve as a general control (in addition to country fixed effects) for differences in the macroeconomic environment of countries. Second, we interact government support ratings with sovereign ratings to control for the financial ability of sovereigns to credibly provide support to ailing banks. ${ }^{11}$ We convert sovereign ratings to numeric representation, with higher numbers representing better ratings.

Only the most recent data can be accessed directly online, while historical data has to be collected manually. We assembled data for two points in time: the end of 2007, before the largescale eruption of the financial crisis, and the end of 2009, after the peak of the financial crisis,

\footnotetext{
${ }^{10}$ See Fitch (2010).

${ }^{11}$ In principle, the support rating could already take the financial capacity of the sovereign into account. However, we also control for this directly.
} 
the adoption of TARP, and the initiation of other large government rescue programs for financial institutions. After cleaning up the data, we have complete data for 895 banks in total. ${ }^{12}$

Table 1 shows some summary statistics for the ratings in 2007 and 2009. As one would expect, long-term credit ratings, as well as individual ratings, are on average somewhat lower after the crisis than before. On the other hand, support ratings and support rating floors have gone up on average. Figure 1 shows the shift in the support ratings: For instance, before the crisis, only 2 percent of banks had a support rating floor of A+. After the crisis, 13 percent of banks are expected to receive this high level of support from their respective governments.

Table 2 shows the level of support ratings in selected countries with large banking centers. ${ }^{13}$ The three countries with the highest level of potential government support (Support Rating Floor) were France, Germany, and Switzerland. At the end 2009, the expected government support in the U.S. for large banks (top 45) was only slightly below the top supporters. Moreover, the U.S. is the country with by far the largest increase in government support between 2007 and 2009. By contrast, in Japan, for example, government support for banks has remained unchanged on average and fell below the U.S. level at the end of 2009.

Table 3 shows some illustrative evidence on factors that determine government support. The famous "Too big to fail" problem suggests that bank size is the main determinant of government support. However, support to SIFIs can be expected for a number of reasons, other than bank size. Indeed, the relationship between bank size and government support seems rather loose for the majority of countries. Simple OLS regressions of Support Rating on bank size for each country show that various size variables (total assets to GDP and market capitalization to GDP) are insignificant in most countries (Table 3).

\section{ESTIMATING THE IMPACT OF GOVERNMENT SUPPORT ON OVERALL RATINGS}

\section{A. Benchmark Estimation}

To estimate the value of support, we first run the following benchmark regression. Our dependent variable is the overall long-term rating of the bank $(L T)$. Because this takes categorical values from 1 to 16 , we conduct ordered probit regressions. The overall rating is explained by two factors: the individual bank's financial strength (INDV) and the expected support (Spprt). In addition, we control for the macroeconomic environment by including sovereign ratings (Sovrgn) and country fixed effects. Our coefficient of interest is $\alpha_{2}$ on Spprt in the following probability estimation equation:

\footnotetext{
12 In particular, we eliminate duplicates within countries (due to holding structures or because banks are incorporated in various states within the U.S.). Also, to avoid overestimating the effect of government support, we eliminate junk bonds (i.e., the category of long-term ratings with $C$ ). They are large outliers and would introduce an upward bias in the estimates.

${ }^{13}$ See Appendix Table 1 for the full list of countries with sample numbers (freq.) and sample share (percent).
} 


$$
L T_{i k}=f\left(\alpha_{0 k}+\alpha_{1} I N D V_{i k}+\alpha_{2} \operatorname{Spprt}_{i k}+\alpha_{3} \operatorname{Svrgn}_{k}+\varepsilon_{i k}\right) .
$$

Column 1 of Table 4 shows the result for the end-2007. The result indicates that an increase in the support rating of one notch causes a right shift within the domain of the normal probability density of about $\alpha_{2}=0.68$. As the long-term rating is categorical, for each rating, 1 to 15 , the intercept (cut) is estimated. Cut 1 to cut 15 show the intercept differentials for each level of the overall rating. Because cut 1 is 5.1 and cut 15 is 15.7 (the difference is 10.6), stepping up one notch in the overall $L T$ rating requires about $0.76(=10.6 / 14)$ of an additional combined score increase, potentially drawing from three factors: individual strength, expected support, and the sovereign rating. This increase is of a similar magnitude as our coefficient of interest $\alpha_{2}$ on Spprt. Hence, if expected support was the only factor that changed, a one-notch higher support rating would increase the overall long-term rating by $0.9(=0.68 / 0.76)$ notches on average.

By calculating the average effect of increasing government support by one notch, we do not take into account possible variations of this effect at different initial rating levels. The effect may be larger at lower rating levels, for example, in the estimates of column (1); moving from cut14 to cut15 (from AA to AAA) requires a step of 0.9 , whereas moving up from cut 11 to cut 12 (BB to $\mathrm{BBB}$ ) requires only a step of 0.66 . In this case, government support is more "valuable" at lower rating levels.

The effect of state support slightly increased at the end-2009. Column 5 of Table 4 shows that the coefficient of interest, $\alpha_{2}$ on Spprt, is now 0.83, while the difference between cut 1 and cut 15 is almost unchanged (i.e., 10.6). Now, a one-notch increase in the support rating increases the overall long-term rating by 1.1 notches on average.

\section{B. Robustness Check}

Our sample includes a number of banks from middle income countries, which may have a lower ability or higher willingness to support their banks. Here, we introduce a dummy variable Dev for the middle income countries to allow them to have different impacts. ${ }^{14}$

$$
L T_{i k}=f\left(\alpha_{0 k}+\alpha_{1} I N D V_{i k}+\alpha_{2} \operatorname{Spprt}_{i k}+\alpha_{3} \operatorname{Svrgn}_{k}+\alpha_{4} \operatorname{Dev}+\alpha_{5} \operatorname{Dev}^{*} \operatorname{Spprt}+\varepsilon_{i k}\right) .
$$

Column 2 and 6 of Table 4 report the results, and there is not much difference for our coefficient of interest $\alpha_{2}$ on Spprt. But now, this is the effect of government support in the advanced economies only. The interaction coefficient $\alpha_{5}$ represents the additional effect in developing countries, and it is almost half of the base effect at the end-2007. That is, a one-notch increase in the support rating increases the overall long-term rating of banks in developing countries by 1.5 notches. At the end-2009, this differential effect between advanced and developing countries is

\footnotetext{
${ }^{14}$ These countries classified as Dev are indicated by * in the country list (Appendix Table 1).
} 
no longer significant, possibly implying that the two sets of countries have become more similar in their capacity and willingness to support their banks.

In some cases, in particular in developing countries, banks are subsidiaries of larger banks of advanced economies. ${ }^{15}$ To isolate the effect of state support from parental support, we include as the control variable the presence of a parent of a bank (Parent), which we interact with the level of support provided by this parent. By doing this, the coefficient $\alpha_{2}$ on Spprt captures only the effect of government support.

$$
L T_{i k}=f\left(\alpha_{0 k}+\alpha_{1} I N D V_{i k}+\alpha_{2} \text { Spprt }_{i k}+\alpha_{3} \text { Svrgn }_{k}+\alpha_{6} \text { Parent }+\alpha_{7} \text { Parent }^{*} \text { Spprt }+\varepsilon_{i k}\right) .
$$

Again, the results are almost unchanged: our coefficient of interest $\alpha_{2}$ on Spprt (see columns 3 and 7 of Table 4) declined marginally. Parental support is about two-thirds of the sovereign support at the end-2007 but not significant at the end-2009. We also run regressions, dropping samples without parental support. The results are almost identical (report omitted).

We combine these two considerations into one regression because parental support is more likely present in developing countries and thus needs to be disentangled from sovereign support. The coefficient $\alpha_{2}$ on Spprt now captures only the effect of government support in advanced economies.

$$
\begin{aligned}
L T_{i k}= & f\left(\alpha_{0 k}+\alpha_{1} I N D V_{i k}+\alpha_{2} \text { Spprt }_{i k}+\alpha_{3} \text { Svrgn }_{k}+\alpha_{4} \text { Dev }+\alpha_{5} \text { Dev }^{*}\right. \text { Spprt } \\
& \left.+\alpha_{6} \text { Parent }+\alpha_{7} \text { Parent }^{*} \text { Spprt }+\alpha_{8} \text { Dev }^{*} \text { Parent }^{*} \text { Spprt }+\varepsilon_{i k}\right) .
\end{aligned}
$$

Once again, the estimated $\alpha_{2}$ on Spprt is very similar (columns 4 and 8 of Table 4 ). A one-notch increase in the support rating increases overall rating at the end-2007 by 0.78 and by 1.1 at the end-2009. Banks in developing countries enjoy higher support at the end-2007 though only at 10 percent significance level. Parental support is significant everywhere and strong also at the end2007. Each of these effects becomes less strong or insignificant at the end-2009, but the interaction effect, that is, parental support in developing countries, has become significant and adds 20 percent to the base effects. The difference between cut 1 and cut 15 increases only marginally at the end-2007, while it shows little change at the end-2009.

\section{Dropping Samples with NF in Support Rating Floor}

We use the Support Rating Floor, in particular the No-Floor ratings, as an additional robustness check. When Fitch is not sure about the lowest level of support a government is willing to offer, it assigns a No-Floor "NF" rating. The existence of a NF rating implies that the potential support comes from a government, not from a parent bank, but the degree of potential support is highly uncertain or likely to be low. Because of this possibly ill-defined value, we check the robustness

\footnotetext{
${ }^{15}$ Some banks in advanced economies are also subsidiaries.
} 
of our estimates by dropping all banks, which have a NF rating from the regression analysis (Table 5).

The coefficient estimates for Spprt becomes larger but so does the difference between cut 1 and cut15. Overall, the impact of increases in the support on the overall credit rating is almost unchanged in the simplest specifications (columns 1 and 5). A one-notch increase in the support rating increases overall rating at the end-2007 by 0.89 and by 1.23 notches at the end-2009. Effects for developing countries and parental supports are more significant, however, in the more elaborative specifications (columns 4 and 8) due to a larger difference between cut 1 and cut 15 estimates. In other words, SIFIs in advanced economies appear to have benefitted less from their governments, as suggested by the simple specification. At the same time, the change between 2007 and 2009 becomes more sizable. A one-notch increase in the support rating increases longterm ratings by 0.55 notches on average at the end-2007 and by 1.05 at the end- 2009 .

Interpreting these results is complicated because it involves making a judgment about the meaning of "not making a judgment," as practiced by Fitch. On the one hand, this specification could be a more precise estimate since it eliminates observations where Fitch is not willing to make a judgment or does not know anything about the expected level of support. On the other hand, this estimate would be downward biased, if a "No-Floor" rating is more likely to be assigned when the government support is considered low (and uncertain). In this last interpretation, these estimates would be a lower bound on the level of the subsidy to SIFIs.

\section{Listed Firm Samples Only}

Listed banks might enjoy a higher level of support from governments since they tend to be more widely followed in the news and held publicly. For the same reason, governments might be more timid to bail out listed banks. To test the hypothesis that there may be large differences between listed and non-listed banks, we run the regression above for a restricted sample of listed banks only. The benchmark results are not affected much by this restriction (Table 6). A onenotch increase in the support rating increases the overall long-term rating by 0.68 , on average, at the end-2007 and by 0.93 at the end-2009. The developing country effect is not significant, and the parental support is significant (and large) only at the end-2007, again suggesting that the differences between the two country groups have leveled.

\section{Using Firm Balance Sheet Information for Listed Firms}

A further concern is that the individual financial strength rating (INDV) by Fitch may include subjective expectation for each bank's profitability and other factors, which might be indirectly influenced by the expectation for support. Therefore, we use firm balance sheet data to model the stand-alone financial strength of the bank rather than using the individual strength rating by Fitch. As proxies for the financial strength of the bank, we use the return on asset (RoA), debt to asset (D/A), and the size (total asset to GDP ratio, TA/GDP). This information is commercially available for listed firms from Thomson Reuter. Figure 2 shows the relationship between the Support Rating Floor and these variables. It shows that the support clearly depends on the size of banks but does not depend on profitability (RoA) or indebtedness (D/A). 
The benchmark results still hold (Table 7). ${ }^{16}$ The simple specification (columns 1 and 5) suggests that a one-notch increase in the support rating increases the overall long-term rating by 0.75 notches on average at the end-2007 and by 0.89 notches at the end-2009. These effects are 0.56 and 0.8 for 2007 and 2009, respectively, according to the most inclusive specification (columns 4 and 8). The developing country effect is as large as the base effect at the end-2007 but becomes insignificant at the end-2009. Parental support is not significant, as somewhat expected for listed firms.

Table 7 also shows some differences in the coefficient estimates of "fundamentals." Rating agencies seem to attach a higher importance to banks' profitability after the crisis, compared to before its advent, and a lower importance to size. The simple leverage ratio has a negative sign but is not significant. This result is consistent with a case in which rating agencies before the crisis focused on risk-weighted measures rather than leverage ratios. It is, however, surprising that the leverage ratio is still an insignificant determinant of long-term ratings after the crisis.

\section{Other Robustness Check}

We rerun the regression using balanced samples for 2007 and 2009 to control for survivorship bias over the crisis. We also omit sovereign ratings from the control variables because, at least for some countries, sovereign ratings and long-term ratings are highly correlated. In both cases, the results for the value of government support are almost identical to the benchmark (reports omitted).

\section{INTERPRETATION AND CONCLUSION}

Section III has provided estimates of the value of the subsidy to SIFIs in terms of the overall ratings. Using the range of our estimates, we can summarize that a one-unit increase in government support for banks in advanced economies has an impact equivalent to 0.55 to 0.9 notches on the overall long-term credit rating at the end-2007. And, this effect increased to 0.8 to 1.23 notches by the end-2009 (Summary Table 8). At the end-2009, the effect of the government support is almost identical between the group of advanced countries and developing countries. Before the crisis, governments in advanced economies played a smaller role in boosting banks' long-term ratings. These results are robust to a number of sample selection tests, such as testing for differential effects across developing and advanced countries, for both listed and non-listed banks, and also correcting for bank parental support and alternative estimations of an individual bank's strength.

In interpreting these results, it is important to check if the averages mask large differences across countries. In fact, the overall rating bonuses in a section of large countries seem remarkably similar (Summary Table 9). For instance, mean support of Japanese banks was unchanged at 3.9 in 2007 and 2009. This implies, based on regressions without distinguishing advanced and

\footnotetext{
${ }^{16}$ Note that, in 2007, no listed banks in our data has the lowest rating, and the cut estimates can be provided only to cut 1 through cut14. In 2009, there are no more AAA listed banks in our data, and the cut estimates can be provided only through cut13.
} 
developing countries, that overall ratings of systemically relevant banks profited by 2.9-3.5 notches from expected government support in 2007, with the value of this support increasing to 3.4-4.2 notches in 2009. For the top 45 U.S. banks, the mean support rating increased from 3.2 in 2007 to 4.1 in 2009. This translates into a 2.4-2.9 overall rating bonus for supported banks in 2007 and a much higher, 3.6-4.5, notch impact in 2009. In Germany, government support started high at 4.4 in 2007 and slightly increased to 4.6 in 2009. This suggests a 3.3-4.0 overall rating advantage of supported banks in 2007 and a 4.1-5.1 notch rating bonus in 2009.

For selected countries that have large banking centers and/or have been affected by the financial crisis, average government support ratings are about 3.6 in 2007 and 3.8 in 2009 on average (see Table 2, based on U.S. top 45 banks). Thus the overall rating bonuses for supported banks in this sample of countries are 2.7-3.2 in 2007 and 3.4-4.2 in 2009.

Our three-notch impact, on average, for advanced countries in 2007 is comparable to the results found by Soussa (2000) and Rimes (2005), although their studies are less rigorous and based on a smaller sample. In addition, Soussa (2000) reports structural annualized interest rate differentials among different credit ratings based on the average cumulative default rates (percent) for 1920-1999, calculated by Moody's. ${ }^{17}$ According to his conversion table, when issuing a five-year bond, a three-notch rating increase translates into a funding advantage of $5 \mathrm{bp}$ to $128 \mathrm{bp}$, depending on the riskiness of the institution..$^{18}$ At the mid-point, it is $66.5 \mathrm{bp}$ for a three-notch improvement, or $22 \mathrm{bp}$ for one-notch improvement. Using this and the overall rating bonuses described in the previous paragraph, we can evaluate the overall funding cost advantage of SIFIs as around 60bp in 2007 and 80bp in 2009.

This is helpful information, for example, if one would like to design a corrective levy on banks, which extracts the value of the subsidy. The funding cost advantage can be decomposed into the level of the government support and the time-varying risk premium. If a corrective levy were to be designed, it should not be affected by short-run market movements but should reflect only the long-run average value of rating bonuses, used here to calculate the total value of the structural government support. As discussed above, we find that the level of the structural government support has increased in most countries in 2009 compared to 2007. Still, we note that our estimate for the value of government support is lower than the real-time market value during crisis.

Our estimate may be also an overestimate of the required tax rate that would neutralize the (implicit) SIFI subsidy, since the competitive advantage of a guaranteed firm versus a nonguaranteed firm can be magnified (the former gains market share and the latter loses market share). One possibility is that the advantages and disadvantages are equally distributed between the two firms. Then, the levy rate that would eliminate the competitive distortion is smaller than the estimated difference in the funding costs. In this simple example, it would be half of the

\footnotetext{
${ }^{17}$ Moody's and Fitch ratings are comparable.

${ }^{18}$ That is, 5-8bp for an A rated bank, 23 bp for a BBB rated bank, 61 bp for a BB rated bank, and 128 bp for a B rated bank.
} 
values given above. Nevertheless, the corrective tax required to correct the distortion of government support would remain sizable. 
Table 1. Summary Statistics for Ratings

\begin{tabular}{lccccc} 
& \multicolumn{5}{c}{2007} \\
\multicolumn{1}{c}{ Variable } & Obs & Mean & Std. Dev. & Min & Max \\
& & & & & \\
LT Rating & 806 & 9.416873 & 3.484826 & 1 & 16 \\
Individual Rating & 815 & 7.522699 & 1.762052 & 3 & 11 \\
Support Rating & 824 & 3.050971 & 1.571256 & 1 & 5 \\
Support Rating Floor & 393 & 7.13486 & 3.010972 & 1 & 16 \\
\hline & & & & & \\
& & & & & \\
\multicolumn{1}{c}{ Variable } & Obs & Mean & Std. Dev. & Min & Max \\
& & & & & \\
LT Rating & 895 & 8.596648 & 3.502858 & 1 & 16 \\
Individual Rating & 895 & 6.52514 & 1.756797 & 1 & 11 \\
Support Rating & 895 & 3.113966 & 1.618674 & 1 & 5 \\
Support Rating Floor & 444 & 7.740991 & 3.357957 & 1 & 16 \\
\hline
\end{tabular}

Table 2. Summary Statistics for Support Ratings for selected countries that have a large banking center and/or have been affected by the financial crisis

\begin{tabular}{|c|c|c|c|c|c|c|c|c|c|}
\hline & \multirow[b]{3}{*}{ Count } & \multicolumn{4}{|c|}{2007} & \multicolumn{4}{|c|}{2009} \\
\hline & & \multicolumn{2}{|c|}{ Support Rating } & \multicolumn{2}{|c|}{ Support Rating Floor } & \multicolumn{2}{|c|}{ Support Rating } & \multicolumn{2}{|c|}{ Support Rating Floor } \\
\hline & & Mean & Std. Dev & Mean & Std. Dev & Mean & Std. Dev & Mean & Std. Dev \\
\hline Australia & 11 & 3.45 & 1.04 & 6.86 & 2.85 & 4.09 & 1.14 & 7.88 & 3.44 \\
\hline Brazil & 18 & 2.44 & 0.89 & 4.00 & 1.26 & 2.78 & 1.26 & 5.29 & 1.38 \\
\hline France & 23 & 4.41 & 1.22 & 9.75 & 0.50 & 4.35 & 1.37 & 11.50 & 1.22 \\
\hline Germany & 27 & 4.42 & 1.03 & 9.65 & 2.74 & 4.59 & 0.69 & 10.17 & 2.39 \\
\hline Greece & 7 & 3.43 & 1.13 & 8.00 & 1.22 & 3.57 & 1.13 & 7.00 & 0.00 \\
\hline Hong Kong & 7 & 3.71 & 0.95 & 5.80 & 2.39 & 3.86 & 1.07 & 6.00 & 2.24 \\
\hline Ireland & 8 & 4.13 & 0.99 & 8.00 & 2.35 & 4.75 & 0.46 & 9.00 & 1.55 \\
\hline Italy & 23 & 3.50 & 1.10 & 6.19 & 2.14 & 3.65 & 1.11 & 6.35 & 2.18 \\
\hline Japan & 28 & 3.85 & 1.17 & 7.64 & 2.25 & 3.86 & 1.24 & 7.81 & 2.87 \\
\hline Netherlands & 10 & 3.43 & 1.62 & 8.17 & 3.92 & 4.00 & 1.49 & 9.71 & 3.95 \\
\hline Portugal & 11 & 3.89 & 1.05 & 7.17 & 3.37 & 3.82 & 1.25 & 7.33 & 2.58 \\
\hline Spain & 42 & 3.29 & 0.64 & 6.21 & 1.20 & 3.29 & 0.64 & 6.35 & 1.42 \\
\hline Switzerland & 10 & 3.50 & 1.96 & 10.00 & 0.00 & 3.50 & 1.96 & 13.00 & 2.65 \\
\hline Turkey & 20 & 2.45 & 0.76 & 3.60 & 0.55 & 2.95 & 1.00 & 5.57 & 0.53 \\
\hline United Kingdom & 39 & 3.68 & 1.45 & 7.81 & 2.48 & 3.74 & 1.45 & 8.81 & 3.54 \\
\hline United States & 213 & 1.97 & 1.55 & 6.03 & 3.72 & 2.17 & 1.77 & 9.70 & 4.09 \\
\hline (U.S.top 45) & 45 & 3.20 & 1.49 & 4.05 & 3.37 & 4.09 & 1.43 & 8.62 & 4.63 \\
\hline Average & 31.9 & 3.46 & 1.18 & 6.99 & 2.14 & 3.71 & 1.20 & 8.24 & 2.39 \\
\hline (Using U.S. top 45) & 20.6 & 3.55 & 1.16 & 7.06 & 2.04 & 3.81 & 1.17 & 8.15 & 2.29 \\
\hline
\end{tabular}


Table 3. OLS Regression Results of Support Rating on Bank Size

Total Asset/GDP '07

\begin{tabular}{|c|c|c|c|c|c|}
\hline \multicolumn{3}{|c|}{ 1otal Asset/GDP 0/ } & \multicolumn{3}{|c|}{ l otal Asset/GDP U9 } \\
\hline $5 \%<$ & $5 \%<,<10 \%$ & not significant & $5 \%<$ & $5 \%<,<10 \%$ & not significant \\
\hline Australia & Canada & Brazil & Australia & Canada & Brazil \\
\hline Italy & Spain & Germany & Italy & United States & Germany \\
\hline Japan & & Greece & Japan & & Greece \\
\hline Philippines & & India & Philippines & & India \\
\hline South Korea & & Indonesia & South Korea & & Poland \\
\hline Taiwan & & Poland & Spain & & Thailand \\
\hline Thailand & & Turkey & Taiwan & & Turkey \\
\hline United Kingdom & & United States & & & United Kingdom \\
\hline & & Venezuela & & & Venezuela \\
\hline
\end{tabular}

\section{Market Capitalization/GDP '07}

\begin{tabular}{|c|c|c|c|c|c|}
\hline $5 \%<$ & $50 \%$ & notsionificont & 50 & & not ionifiont \\
\hline $\begin{array}{l}\text { Australia } \\
\text { Italy } \\
\text { Japan } \\
\text { South Korea } \\
\text { Thailand }\end{array}$ & Spain & $\begin{array}{l}\text { Brazil } \\
\text { Canada } \\
\text { Germany } \\
\text { Greece } \\
\text { India } \\
\text { Indonesia } \\
\text { Philippines } \\
\text { Poland } \\
\text { Taiwan } \\
\text { Turkey } \\
\text { United Kingdom } \\
\text { United States } \\
\text { Venezuela }\end{array}$ & $\begin{array}{l}\text { Australia } \\
\text { Italy } \\
\text { Japan } \\
\text { South Korea } \\
\text { Spain }\end{array}$ & & $\begin{array}{l}\text { Brazil } \\
\text { Canada } \\
\text { Germany } \\
\text { Greece } \\
\text { India } \\
\text { Philippines } \\
\text { Poland } \\
\text { Taiwan } \\
\text { Thailand } \\
\text { Turkey } \\
\text { United Kingdom } \\
\text { United States } \\
\text { Venezuela }\end{array}$ \\
\hline
\end{tabular}

Note: Bank size is measured by the Total Asset/GDP ratio or the Market Capitalization/GDP ratio. Simple OLS regressions are conducted for each country with more than 10 banks. Countries are sorted according to the significance level of the coefficients on the size variable. Significance levels are shown in the first rows. The results with the Total Asset/Private Credit ratio as a size variable are almost identical to the ones using the Total Asset/GDP ratio (not shown). 
Table 4. Benchmark Ordered Probit

\begin{tabular}{|c|c|c|c|c|c|c|c|c|}
\hline & \multicolumn{4}{|c|}{ end-2007 } & \multicolumn{4}{|c|}{ end-2009 } \\
\hline & (1) & (2) & (3) & (4) & (5) & $(6)$ & (7) & (8) \\
\hline INDV & $\begin{array}{c}0.8420 * * * \\
{[13.923]}\end{array}$ & $\begin{array}{c}0.8587 * * * \\
{[13.221]}\end{array}$ & $\begin{array}{c}0.8911 * * * \\
{[14.063]}\end{array}$ & $\begin{array}{c}0.8981 * * * \\
{[13.543]}\end{array}$ & $\begin{array}{c}0.6426^{* * *} \\
{[15.405]}\end{array}$ & $\begin{array}{c}0.6295^{* * *} * \\
{[15.128]}\end{array}$ & $\begin{array}{c}0.6405 * * * \\
{[15.179]}\end{array}$ & $\begin{array}{c}0.6324 * * * \\
{[14.999]}\end{array}$ \\
\hline Spprt & $\begin{array}{c}0.6769 * * * \\
{[14.565]}\end{array}$ & $\begin{array}{c}0.6488 * * * \\
{[14.687]}\end{array}$ & $\begin{array}{c}0.6043 * * * \\
{[12.861]}\end{array}$ & $\begin{array}{c}0.5981 * * * \\
{[13.073]}\end{array}$ & $\begin{array}{c}0.8347 * * * \\
{[24.457]}\end{array}$ & $\begin{array}{c}0.8343 * * * \\
{[20.653]}\end{array}$ & $\begin{array}{c}0.8190 * * * \\
{[23.607]}\end{array}$ & $\begin{array}{c}0.8330 * * * \\
{[20.281]}\end{array}$ \\
\hline Svrgn & $\begin{array}{c}0.1586 * * * \\
{[7.596]}\end{array}$ & $\begin{array}{c}0.1580 * * * \\
{[5.661]}\end{array}$ & $\begin{array}{c}0.1496^{* * *} \\
{[7.017]}\end{array}$ & $\begin{array}{c}0.1505^{* * *} \\
{[5.319]}\end{array}$ & $\begin{array}{c}0.2043 * * * \\
{[15.867]}\end{array}$ & $\begin{array}{c}0.1862 * * * \\
{[9.528]}\end{array}$ & $\begin{array}{c}0.2034 * * * \\
{[15.375]}\end{array}$ & $\begin{array}{c}0.1888 * * * \\
{[9.454]}\end{array}$ \\
\hline Dev & & $\begin{array}{c}-1.0502 * * \\
{[-2.061]}\end{array}$ & & $\begin{array}{l}-0.8090 \\
{[-1.548]}\end{array}$ & & $\begin{array}{l}-0.2942 \\
{[-0.913]}\end{array}$ & & $\begin{array}{l}-0.1139 \\
{[-0.346]}\end{array}$ \\
\hline Dev*Spprt & & $\begin{array}{c}0.3413^{* * *} * \\
{[3.122]}\end{array}$ & & $\begin{array}{l}0.2349^{*} \\
{[1.818]}\end{array}$ & & $\begin{array}{c}0.0411 \\
{[0.524]}\end{array}$ & & $\begin{array}{l}-0.0673 \\
{[-0.795]}\end{array}$ \\
\hline Parent & & & $\begin{array}{c}-1.4963 * * * \\
{[-3.598]}\end{array}$ & $\begin{array}{c}-1.3474 * * * \\
{[-2.802]}\end{array}$ & & & $\begin{array}{l}-0.4807 \\
{[-1.379]}\end{array}$ & $\begin{array}{c}-0.7939 * \\
{[-1.812]}\end{array}$ \\
\hline Parent*Spprt & & & $\begin{array}{c}0.4485^{* * *} \\
{[4.621]}\end{array}$ & $\begin{array}{c}0.3912 * * * \\
{[3.614]}\end{array}$ & & & $\begin{array}{c}0.1304 \\
{[1.557]}\end{array}$ & $\begin{array}{c}0.1682 * \\
{[1.775]}\end{array}$ \\
\hline Dev*Parent*Spprt & & & & $\begin{array}{c}0.0581 \\
{[0.880]}\end{array}$ & & & & $\begin{array}{c}0.1491 * * * \\
{[2.764]}\end{array}$ \\
\hline cut 1 & $\begin{array}{c}5.1438 * * * \\
{[13.138]}\end{array}$ & $\begin{array}{c}4.7261 * * * \\
{[7.660]}\end{array}$ & $\begin{array}{c}5.1591 * * * \\
{[12.621]}\end{array}$ & $\begin{array}{c}4.8311 * * * \\
{[7.864]}\end{array}$ & $\begin{array}{c}4.6659 * * * \\
{[18.550]}\end{array}$ & $\begin{array}{c}4.3349 * * * \\
{[10.552]}\end{array}$ & $\begin{array}{c}4.6057 * * * \\
{[17.593]}\end{array}$ & $\begin{array}{c}4.3688 * * * \\
{[10.248]}\end{array}$ \\
\hline cut 2 & $\begin{array}{c}5.6144 * * * \\
{[14.130]}\end{array}$ & $\begin{array}{c}5.2603 * * * \\
{[8.749]}\end{array}$ & $\begin{array}{c}5.6267 * * * \\
{[13.540]}\end{array}$ & $\begin{array}{c}5.3506^{* * *} \\
{[8.909]}\end{array}$ & $\begin{array}{c}5.4591 * * * \\
{[22.052]}\end{array}$ & $\begin{array}{c}5.1070 * * * \\
{[12.840]}\end{array}$ & $\begin{array}{c}5.3929 * * * \\
{[20.849]}\end{array}$ & $\begin{array}{c}5.1293 * * * \\
{[12.391]}\end{array}$ \\
\hline cut3 & $\begin{array}{c}6.2440 * * * \\
{[15.100]}\end{array}$ & $\begin{array}{c}5.9880 * * * \\
{[10.181]}\end{array}$ & $\begin{array}{c}6.2347 * * * \\
{[14.423]}\end{array}$ & $\begin{array}{c}6.0347 * * * \\
{[10.175]}\end{array}$ & $\begin{array}{c}6.0067 * * * \\
{[24.079]}\end{array}$ & $\begin{array}{c}5.6760 * * * \\
{[14.737]}\end{array}$ & $\begin{array}{c}5.9359 * * * \\
{[22.636]}\end{array}$ & $\begin{array}{c}5.6919 * * * \\
{[14.126]}\end{array}$ \\
\hline cut4 & $\begin{array}{c}7.0020^{* * *} \\
{[15.560]}\end{array}$ & $\begin{array}{c}6.9135^{* * *} * \\
{[11.533]}\end{array}$ & $\begin{array}{c}6.9829 * * * \\
{[14.898]}\end{array}$ & $\begin{array}{c}6.9280 * * * \\
{[11.432]}\end{array}$ & $\begin{array}{c}6.3882 * * * \\
{[24.181]}\end{array}$ & $\begin{array}{c}6.0827 * * * \\
{[15.886]}\end{array}$ & $\begin{array}{c}6.3148 * * * \\
{[22.737]}\end{array}$ & $\begin{array}{c}6.0937 * * * \\
{[15.153]}\end{array}$ \\
\hline cut5 & $\begin{array}{c}7.7227 * * * \\
{[15.807]}\end{array}$ & $\begin{array}{c}7.6818^{* * *} * \\
{[12.323]}\end{array}$ & $\begin{array}{c}7.7201 * * * \\
{[15.165]}\end{array}$ & $\begin{array}{c}7.6966^{* * *} \\
{[12.261]}\end{array}$ & $\begin{array}{c}6.9726 * * * \\
{[24.629]}\end{array}$ & $\begin{array}{c}6.6471 * * * \\
{[17.059]}\end{array}$ & $\begin{array}{c}6.8986^{* * * *} \\
{[23.232]}\end{array}$ & $\begin{array}{c}6.6562 * * * \\
{[16.334]}\end{array}$ \\
\hline cut6 & $\begin{array}{c}8.0699 * * * \\
{[15.857]}\end{array}$ & $\begin{array}{c}8.0927 * * * \\
{[12.680]}\end{array}$ & $\begin{array}{c}8.0856^{* * *} \\
{[15.226]}\end{array}$ & $\begin{array}{c}8.1140 * * * \\
{[12.690]}\end{array}$ & $\begin{array}{c}7.4864 * * * \\
{[25.182]}\end{array}$ & $\begin{array}{c}7.1676^{* * *} \\
{[18.207]}\end{array}$ & $\begin{array}{c}7.4154 * * * \\
{[23.976]}\end{array}$ & $\begin{array}{c}7.1813 * * * \\
{[17.556]}\end{array}$ \\
\hline cut7 & $\begin{array}{c}8.8427 * * * \\
{[15.776]}\end{array}$ & $\begin{array}{c}8.8983 * * * \\
{[13.174]}\end{array}$ & $\begin{array}{c}8.9097 * * * \\
{[15.091]}\end{array}$ & $\begin{array}{c}8.9569 * * * \\
{[13.161]}\end{array}$ & $\begin{array}{c}8.3101 * * * \\
{[25.602]}\end{array}$ & $\begin{array}{c}7.9549 * * * \\
{[19.567]}\end{array}$ & $\begin{array}{c}8.2455^{* * * *} \\
{[24.588]}\end{array}$ & $\begin{array}{c}7.9843 * * * \\
{[19.005]}\end{array}$ \\
\hline cut 8 & $\begin{array}{c}9.5181 * * * \\
{[16.108]}\end{array}$ & $\begin{array}{c}9.5750 * * * \\
{[13.729]}\end{array}$ & $\begin{array}{c}9.6097 * * * \\
{[15.441]}\end{array}$ & $\begin{array}{c}9.6537 * * * \\
{[13.732]}\end{array}$ & $\begin{array}{c}9.0993 * * * \\
{[26.427]}\end{array}$ & $\begin{array}{c}8.7386^{* * *} \\
{[20.599]}\end{array}$ & $\begin{array}{c}9.0371 * * * \\
{[25.480]}\end{array}$ & $\begin{array}{c}8.7785 * * * \\
{[20.100]}\end{array}$ \\
\hline cut9 & $\begin{array}{c}10.1986 * * * \\
{[16.495]}\end{array}$ & $\begin{array}{c}10.2607 * * * \\
{[14.239]}\end{array}$ & $\begin{array}{c}10.3152 * * * \\
{[15.822]}\end{array}$ & $\begin{array}{c}10.3616^{* * *} \\
{[14.242]}\end{array}$ & $\begin{array}{c}9.7689 * * * \\
{[27.238]}\end{array}$ & $\begin{array}{c}9.3845 * * * \\
{[21.584]}\end{array}$ & $\begin{array}{c}9.7077 * * * \\
{[26.344]}\end{array}$ & $\begin{array}{c}9.4296 * * * \\
{[21.102]}\end{array}$ \\
\hline cut 10 & $\begin{array}{c}11.2063 * * * \\
{[16.840]}\end{array}$ & $\begin{array}{c}11.3023 * * * \\
{[14.814]}\end{array}$ & $\begin{array}{c}11.3602 * * * \\
{[16.159]}\end{array}$ & $\begin{array}{c}11.4391 * * * \\
{[14.823]}\end{array}$ & $\begin{array}{c}10.5526^{* * *} * \\
{[27.772]}\end{array}$ & $\begin{array}{c}10.1858 * * * \\
{[22.368]}\end{array}$ & $\begin{array}{c}10.4958 * * * \\
{[26.943]}\end{array}$ & $\begin{array}{c}10.2416^{* * *} \\
{[21.921]}\end{array}$ \\
\hline cut11 & $\begin{array}{c}11.9928 * * * \\
{[17.041]}\end{array}$ & $\begin{array}{c}12.0593 * * * \\
{[15.094]}\end{array}$ & $\begin{array}{c}12.1686 * * * \\
{[16.373]}\end{array}$ & $\begin{array}{c}12.2192 * * * \\
{[15.113]}\end{array}$ & $\begin{array}{c}11.2286 * * * \\
{[28.393]}\end{array}$ & $\begin{array}{c}10.8511 * * * \\
{[22.988]}\end{array}$ & $\begin{array}{c}11.1723 * * * \\
{[27.627]}\end{array}$ & $\begin{array}{c}10.9120 * * * \\
{[22.552]}\end{array}$ \\
\hline cut 12 & $\begin{array}{c}12.6501 * * * \\
{[17.247]}\end{array}$ & $\begin{array}{c}12.7082 * * * \\
{[15.468]}\end{array}$ & $\begin{array}{c}12.8473 * * * \\
{[16.538]}\end{array}$ & $\begin{array}{c}12.8895 * * * \\
{[15.463]}\end{array}$ & $\begin{array}{c}12.3060 * * * \\
{[28.760]}\end{array}$ & $\begin{array}{c}11.9222 * * * \\
{[23.428]}\end{array}$ & $\begin{array}{c}12.2510 * * * \\
{[28.013]}\end{array}$ & $\begin{array}{c}11.9899 * * * \\
{[22.977]}\end{array}$ \\
\hline cut 13 & $\begin{array}{c}13.7266^{* * *} * \\
{[17.488]}\end{array}$ & $\begin{array}{c}13.7854 * * * \\
{[15.919]}\end{array}$ & $\begin{array}{c}13.9701 * * * \\
{[16.745]}\end{array}$ & $\begin{array}{c}14.0093 * * * \\
{[15.856]}\end{array}$ & $\begin{array}{c}13.6824 * * * \\
{[27.436]}\end{array}$ & $\begin{array}{c}13.2893 * * * \\
{[23.149]}\end{array}$ & $\begin{array}{c}13.6336 * * * \\
{[26.774]}\end{array}$ & $\begin{array}{c}13.3626^{* * *} \\
{[22.705]}\end{array}$ \\
\hline cut 14 & $\begin{array}{c}14.7401 * * * \\
{[16.568]}\end{array}$ & $\begin{array}{c}14.8605 * * * \\
{[15.501]}\end{array}$ & $\begin{array}{c}14.9819 * * * \\
{[15.999]}\end{array}$ & $\begin{array}{c}15.0838 * * * \\
{[15.438]}\end{array}$ & $\begin{array}{c}15.0518 * * * \\
{[27.044]}\end{array}$ & $\begin{array}{c}14.6514 * * * \\
{[23.621]}\end{array}$ & $\begin{array}{c}14.9996 * * * \\
{[26.511]}\end{array}$ & $\begin{array}{c}14.7263^{* * *} * \\
{[23.301]}\end{array}$ \\
\hline cut 15 & $\begin{array}{c}15.6582 * * * \\
{[17.376]}\end{array}$ & $\begin{array}{c}15.7382 * * * \\
{[16.165]}\end{array}$ & $\begin{array}{c}15.8251 * * * \\
{[16.776]}\end{array}$ & $\begin{array}{c}15.9054 * * * \\
{[16.066]}\end{array}$ & $\begin{array}{c}15.2666^{* * *} * \\
{[24.419]}\end{array}$ & $\begin{array}{c}14.8644 * * * \\
{[21.838]}\end{array}$ & $\begin{array}{c}15.2088 * * * \\
{[24.151]}\end{array}$ & $\begin{array}{c}14.9382 * * * \\
{[21.639]}\end{array}$ \\
\hline Obs. & 767 & 738 & 767 & 738 & 860 & 822 & 860 & 822 \\
\hline Wald Chi2 & 305.6 & 298.9 & 279.6 & 283.4 & 894.8 & 847.7 & 930.3 & 904.6 \\
\hline Prob $>$ Chi2 & 0 & 0 & 0 & 0 & 0 & 0 & 0 & 0 \\
\hline Pseudo R2 & 0.349 & 0.360 & 0.359 & 0.368 & 0.348 & 0.348 & 0.348 & 0.350 \\
\hline
\end{tabular}


Table 5. Dropping Samples with NF in Support Floor Rating

end-2007 end-2009

\begin{tabular}{|c|c|c|c|c|c|c|c|c|}
\hline & & & & & & & & \\
\hline & (1) & $(2)$ & (3) & (4) & (5) & (6) & $(7)$ & $(8)$ \\
\hline INDV & $\begin{array}{c}0.7117 * * * \\
{[10.788]}\end{array}$ & $\begin{array}{c}0.7116^{* * *} \\
{[10.209]}\end{array}$ & $\begin{array}{c}0.7614 * * * \\
{[10.758]}\end{array}$ & $\begin{array}{c}0.7486 * * * \\
{[10.334]}\end{array}$ & $\begin{array}{c}0.5377 * * * \\
{[13.578]}\end{array}$ & $\begin{array}{c}0.5285^{* * *} \\
{[13.345]}\end{array}$ & $\begin{array}{c}0.5313 * * * \\
{[13.339]}\end{array}$ & $\begin{array}{c}0.5242 * * * \\
{[13.259]}\end{array}$ \\
\hline Spprt & $\begin{array}{c}0.7524 * * * \\
{[8.676]}\end{array}$ & $\begin{array}{c}0.6224 * * * \\
{[8.186]}\end{array}$ & $\begin{array}{c}0.6092 * * * \\
{[6.990]}\end{array}$ & $\begin{array}{c}0.5120 * * * \\
{[6.803]}\end{array}$ & $\begin{array}{c}1.1960 * * * \\
{[18.688]}\end{array}$ & $\begin{array}{c}1.1366^{* * *} \\
{[15.173]}\end{array}$ & $\begin{array}{c}1.1518 * * * \\
{[18.357]}\end{array}$ & $\begin{array}{c}1.0863^{* * *} * \\
{[14.841]}\end{array}$ \\
\hline Svrgn & $\begin{array}{c}0.2018 * * * \\
{[7.450]}\end{array}$ & $\begin{array}{c}0.2028 * * * \\
{[6.113]}\end{array}$ & $\begin{array}{c}0.2047 * * * \\
{[7.243]}\end{array}$ & $\begin{array}{c}0.2039 * * * \\
{[6.058]}\end{array}$ & $\begin{array}{c}0.2682 * * * \\
{[14.555]}\end{array}$ & $\begin{array}{c}0.2561 * * * \\
{[9.588]}\end{array}$ & $\begin{array}{c}0.2695 * * * \\
{[14.295]}\end{array}$ & $\begin{array}{c}0.2679 * * * \\
{[9.932]}\end{array}$ \\
\hline Dev & & $\begin{array}{c}-2.3885^{* *} \\
{[-2.292]}\end{array}$ & & $\begin{array}{c}-2.0458^{*} \\
{[-1.801]}\end{array}$ & & $\begin{array}{c}-1.8105^{* *} \\
{[-2.560]}\end{array}$ & & $\begin{array}{c}-1.5614^{* *} \\
{[-2.213]}\end{array}$ \\
\hline Dev*Spprt & & $\begin{array}{c}0.6554 * * * \\
{[2.820]}\end{array}$ & & $\begin{array}{c}0.5103^{*} \\
{[1.909]}\end{array}$ & & $\begin{array}{c}0.4671 * * * \\
{[2.742]}\end{array}$ & & $\begin{array}{c}0.3558^{* *} \\
{[2.025]}\end{array}$ \\
\hline Parent & & & $\begin{array}{c}-2.2050^{* * *} \\
{[-4.386]}\end{array}$ & $\begin{array}{c}-2.3364 * * * \\
{[-3.972]}\end{array}$ & & & $\begin{array}{l}-0.7300 \\
{[-1.369]}\end{array}$ & $\begin{array}{l}-1.4003^{*} \\
{[-1.935]}\end{array}$ \\
\hline Parent*Spprt & & & $\begin{array}{c}0.5985 * * * \\
{[5.114]}\end{array}$ & $\begin{array}{c}0.5936^{* * *} \\
{[4.549]}\end{array}$ & & & $\begin{array}{l}0.1716 \\
{[1.413]}\end{array}$ & $\begin{array}{l}0.2832^{*} \\
{[1.883]}\end{array}$ \\
\hline Dev*Parent*Spprt & & & & $\begin{array}{l}0.0887 \\
{[1.334]}\end{array}$ & & & & $\begin{array}{c}0.1481 * * \\
{[2.191]}\end{array}$ \\
\hline cut 1 & $\begin{array}{c}3.6635^{* * * *} \\
{[6.011]}\end{array}$ & $\begin{array}{c}2.2083^{* * *} \\
{[2.901]}\end{array}$ & $\begin{array}{c}3.2336^{* * *} * \\
{[5.768]}\end{array}$ & $\begin{array}{c}1.8381^{* *} \\
{[2.310]}\end{array}$ & $\begin{array}{c}3.5287^{* * *} \\
{[8.314]}\end{array}$ & $\begin{array}{c}2.2814 * * * \\
{[3.434]}\end{array}$ & $\begin{array}{c}3.2393 * * * \\
{[7.673]}\end{array}$ & $\begin{array}{c}1.9816^{* * * *} \\
{[3.147]}\end{array}$ \\
\hline cut2 & $\begin{array}{c}4.4863 * * * \\
{[7.976]}\end{array}$ & $\begin{array}{c}3.1524 * * * \\
{[4.447]}\end{array}$ & $\begin{array}{c}4.2879 * * * \\
{[7.180]}\end{array}$ & $\begin{array}{c}3.0437 * * * \\
{[4.169]}\end{array}$ & $\begin{array}{c}5.3231 * * * \\
{[15.663]}\end{array}$ & $\begin{array}{c}4.3345^{* * *} \\
{[6.618]}\end{array}$ & $\begin{array}{c}5.0909 * * * \\
{[15.009]}\end{array}$ & $\begin{array}{c}4.1182 * * * \\
{[6.701]}\end{array}$ \\
\hline cut3 & $\begin{array}{c}5.6116 * * * \\
{[10.134]}\end{array}$ & $\begin{array}{c}4.4846^{* * * *} \\
{[7.107]}\end{array}$ & $\begin{array}{c}5.3615^{* * * *} \\
{[9.088]}\end{array}$ & $\begin{array}{c}4.2803 * * * \\
{[6.472]}\end{array}$ & $\begin{array}{c}6.4094 * * * \\
{[19.805]}\end{array}$ & $\begin{array}{c}5.5256^{* * *} * \\
{[10.121]}\end{array}$ & $\begin{array}{c}6.1761 * * * \\
{[17.797]}\end{array}$ & $\begin{array}{c}5.3317 * * * \\
{[9.673]}\end{array}$ \\
\hline cut4 & $\begin{array}{c}6.7472 * * * \\
{[11.272]}\end{array}$ & $\begin{array}{c}5.8354 * * * \\
{[9.127]}\end{array}$ & $\begin{array}{c}6.4561 * * * \\
{[10.245]}\end{array}$ & $\begin{array}{c}5.5485^{* * * *} \\
{[8.355]}\end{array}$ & $\begin{array}{c}7.1030 * * * \\
{[21.003]}\end{array}$ & $\begin{array}{c}6.3371 * * * \\
{[12.035]}\end{array}$ & $\begin{array}{c}6.8641 * * * \\
{[18.803]}\end{array}$ & $\begin{array}{c}6.1348^{* * * *} \\
{[11.182]}\end{array}$ \\
\hline cut5 & $\begin{array}{c}7.5645^{* * * *} \\
{[11.682]}\end{array}$ & $\begin{array}{c}6.7822^{* * *} \\
{[10.198]}\end{array}$ & $\begin{array}{c}7.2937 * * * \\
{[10.743]}\end{array}$ & $\begin{array}{c}6.4915^{* * *} \\
{[9.571]}\end{array}$ & $\begin{array}{c}7.8613 * * * \\
{[22.623]}\end{array}$ & $\begin{array}{c}7.1633^{* * *} \\
{[13.901]}\end{array}$ & $\begin{array}{c}7.6227 * * * \\
{[20.605]}\end{array}$ & $\begin{array}{c}6.9618^{* * *} \\
{[13.114]}\end{array}$ \\
\hline cut6 & $\begin{array}{c}8.0367 * * * \\
{[11.697]}\end{array}$ & $\begin{array}{c}7.3819^{* * *} \\
{[10.566]}\end{array}$ & $\begin{array}{c}7.8104 * * * \\
{[10.803]}\end{array}$ & $\begin{array}{c}7.1144 * * * \\
{[10.168]}\end{array}$ & $\begin{array}{c}8.7094 * * * \\
{[23.462]}\end{array}$ & $\begin{array}{c}8.1753 * * * \\
{[16.068]}\end{array}$ & $\begin{array}{c}8.4835 * * * \\
{[22.015]}\end{array}$ & $\begin{array}{c}7.9966^{* * * *} \\
{[15.344]}\end{array}$ \\
\hline cut7 & $\begin{array}{c}8.8291 * * * \\
{[11.628]}\end{array}$ & $\begin{array}{c}8.3469 * * * \\
{[10.841]}\end{array}$ & $\begin{array}{c}8.6875^{* * * *} \\
{[10.749]}\end{array}$ & $\begin{array}{c}8.1545 * * * \\
{[10.491]}\end{array}$ & $\begin{array}{c}9.8252 * * * \\
{[23.887]}\end{array}$ & $\begin{array}{c}9.3910^{* * *} \\
{[17.976]}\end{array}$ & $\begin{array}{c}9.6165 * * * \\
{[22.824]}\end{array}$ & $\begin{array}{c}9.2585 * * * \\
{[17.254]}\end{array}$ \\
\hline cut8 & $\begin{array}{c}9.3034 * * * \\
{[11.749]}\end{array}$ & $\begin{array}{c}8.8065 * * * \\
{[10.980]}\end{array}$ & $\begin{array}{c}9.1956^{* * *} \\
{[10.900]}\end{array}$ & $\begin{array}{c}8.6445 * * * \\
{[10.669]}\end{array}$ & $\begin{array}{c}10.5599 * * * \\
{[24.542]}\end{array}$ & $\begin{array}{c}10.1110 * * * \\
{[18.742]}\end{array}$ & $\begin{array}{c}10.3571 * * * \\
{[23.534]}\end{array}$ & $\begin{array}{c}9.9947 * * * \\
{[18.058]}\end{array}$ \\
\hline cut9 & $\begin{array}{c}10.0806 * * * \\
{[11.994]}\end{array}$ & $\begin{array}{c}9.6128 * * * \\
{[11.248]}\end{array}$ & $\begin{array}{c}10.0279 * * * \\
{[11.162]}\end{array}$ & $\begin{array}{c}9.5126^{* * *} \\
{[10.976]}\end{array}$ & $\begin{array}{c}11.4063 * * * \\
{[24.976]}\end{array}$ & $\begin{array}{c}10.9415^{* * *} \\
{[19.663]}\end{array}$ & $\begin{array}{c}11.2078^{* * *} \\
{[24.095]}\end{array}$ & $\begin{array}{c}10.8360^{* * *} \\
{[18.997]}\end{array}$ \\
\hline cut 10 & $\begin{array}{c}11.0101 * * * \\
{[12.242]}\end{array}$ & $\begin{array}{c}10.5889 * * * \\
{[11.592]}\end{array}$ & $\begin{array}{c}11.0231 * * * \\
{[11.402]}\end{array}$ & $\begin{array}{c}10.5578^{* * *} \\
{[11.352]}\end{array}$ & $\begin{array}{c}12.2920 * * * \\
{[25.462]}\end{array}$ & $\begin{array}{c}11.8298^{* * *} \\
{[20.447]}\end{array}$ & $\begin{array}{c}12.0991 * * * \\
{[24.613]}\end{array}$ & $\begin{array}{c}11.7408^{* * *} \\
{[19.811]}\end{array}$ \\
\hline cut11 & $\begin{array}{c}11.9133 * * * \\
{[12.495]}\end{array}$ & $\begin{array}{c}11.4426^{* * *} \\
{[11.902]}\end{array}$ & $\begin{array}{c}11.9633 * * * \\
{[11.663]}\end{array}$ & $\begin{array}{c}11.4478 * * * \\
{[11.689]}\end{array}$ & $\begin{array}{c}13.1112 * * * \\
{[26.225]}\end{array}$ & $\begin{array}{c}12.6184 * * * \\
{[21.204]}\end{array}$ & $\begin{array}{c}12.9164^{* * *} \\
{[25.429]}\end{array}$ & $\begin{array}{c}12.5330^{* * *} \\
{[20.587]}\end{array}$ \\
\hline cut 12 & $\begin{array}{c}12.5487 * * * \\
{[12.671]}\end{array}$ & $\begin{array}{c}12.0488 * * * \\
{[12.199]}\end{array}$ & $\begin{array}{c}12.6253^{* * *} \\
{[11.812]}\end{array}$ & $\begin{array}{c}12.0776^{* * * *} \\
{[11.982]}\end{array}$ & $\begin{array}{c}14.3461 * * * \\
{[26.799]}\end{array}$ & $\begin{array}{c}13.8195 * * * \\
{[21.896]}\end{array}$ & $\begin{array}{c}14.1452^{* * *} \\
{[26.002]}\end{array}$ & $\begin{array}{c}13.7323^{* * *} \\
{[21.281]}\end{array}$ \\
\hline cut 13 & $\begin{array}{c}13.6056^{* * *} \\
{[12.969]}\end{array}$ & $\begin{array}{c}13.0613 * * * \\
{[12.588]}\end{array}$ & $\begin{array}{c}13.7349 * * * \\
{[12.121]}\end{array}$ & $\begin{array}{c}13.1330 * * * \\
{[12.369]}\end{array}$ & $\begin{array}{c}15.6739 * * * \\
{[26.463]}\end{array}$ & $\begin{array}{c}15.1248^{* * *} \\
{[22.159]}\end{array}$ & $\begin{array}{c}15.4710^{* * *} \\
{[25.721]}\end{array}$ & $\begin{array}{c}15.0304^{* * *} \\
{[21.570]}\end{array}$ \\
\hline cut14 & $\begin{array}{c}14.6481 * * * \\
{[12.684]}\end{array}$ & $\begin{array}{c}14.0657^{* * *} \\
{[12.463]}\end{array}$ & $\begin{array}{c}14.7693 * * * \\
{[11.978]}\end{array}$ & $\begin{array}{c}14.1333^{* * *} \\
{[12.292]}\end{array}$ & $\begin{array}{c}16.9499 * * * \\
{[26.487]}\end{array}$ & $\begin{array}{c}16.3903 * * * \\
{[22.759]}\end{array}$ & $\begin{array}{c}16.7405 * * * \\
{[25.947]}\end{array}$ & $\begin{array}{c}16.2911 * * * \\
{[22.343]}\end{array}$ \\
\hline cut 15 & $\begin{array}{c}15.5081 * * * \\
{[13.354]} \\
\end{array}$ & $\begin{array}{c}14.9093 * * * \\
{[13.118]} \\
\end{array}$ & $\begin{array}{c}15.5517^{* * *} \\
{[12.580]} \\
\end{array}$ & $\begin{array}{c}14.9165^{* * *} \\
{[12.901]} \\
\end{array}$ & $\begin{array}{c}17.1565^{* * *} \\
{[24.726]} \\
\end{array}$ & $\begin{array}{c}16.5953^{* * *} \\
{[21.622]} \\
\end{array}$ & $\begin{array}{c}16.9427^{* * *} * \\
{[24.343]} \\
\end{array}$ & $\begin{array}{c}16.4956^{* * *} * \\
{[21.288]} \\
\end{array}$ \\
\hline Obs. & 550 & 533 & 550 & 533 & 615 & 597 & 615 & 597 \\
\hline Wald Chi2 & 168.6 & 192.2 & 151.1 & 179.0 & 704.4 & 666.5 & 715.2 & 688.7 \\
\hline Prob $>$ & 0 & 0 & 0 & 0 & 0 & 0 & 0 & 0 \\
\hline Pseudo R2 & 0.344 & 0.353 & 0.360 & 0.367 & 0.388 & 0.395 & 0.389 & 0.399 \\
\hline
\end{tabular}


Table 6. Listed Firm Samples Only

end-2007

(1)

(3)

(4)

end-2009

\begin{tabular}{|c|c|c|c|c|c|c|c|c|}
\hline & (1) & (2) & (3) & (4) & (5) & (6) & (7) & (8) \\
\hline INDV & $\begin{array}{c}0.8435^{* * *} * \\
{[7.953]}\end{array}$ & $\begin{array}{c}0.8889^{* * *} * \\
{[7.418]}\end{array}$ & $\begin{array}{c}0.9035^{* * *} \\
{[8.259]}\end{array}$ & $\begin{array}{c}0.9464 * * * \\
{[7.754]}\end{array}$ & $\begin{array}{c}0.8434 * * * \\
{[9.411]}\end{array}$ & $\begin{array}{c}0.8428 * * * \\
{[8.997]}\end{array}$ & $\begin{array}{c}0.8443 * * * \\
{[9.368]}\end{array}$ & $\begin{array}{c}0.8427 * * * \\
{[8.848]}\end{array}$ \\
\hline Spprt & $\begin{array}{c}0.5808^{* * * *} \\
{[8.864]}\end{array}$ & $\begin{array}{c}0.6056^{* * *} \\
{[9.577]}\end{array}$ & $\begin{array}{c}0.5291 * * * \\
{[8.029]}\end{array}$ & $\begin{array}{c}0.5559 * * * \\
{[8.648]}\end{array}$ & $\begin{array}{c}0.7449 * * * \\
{[12.844]}\end{array}$ & $\begin{array}{c}0.7742 * * * \\
{[10.775]}\end{array}$ & $\begin{array}{c}0.7277 * * * \\
{[12.378]}\end{array}$ & $\begin{array}{c}0.7530 * * * \\
{[10.475]}\end{array}$ \\
\hline Svrgn & $\begin{array}{c}0.2202 * * * \\
{[6.831]}\end{array}$ & $\begin{array}{c}0.2302 * * * \\
{[4.958]}\end{array}$ & $\begin{array}{c}0.2075^{* * *} * \\
{[6.186]}\end{array}$ & $\begin{array}{c}0.2146 * * * \\
{[4.641]}\end{array}$ & $\begin{array}{c}0.2408 * * * \\
{[9.985]}\end{array}$ & $\begin{array}{c}0.2201 * * * \\
{[6.569]}\end{array}$ & $\begin{array}{c}0.2407 * * * \\
{[9.917]}\end{array}$ & $\begin{array}{c}0.2168 * * * \\
{[6.357]}\end{array}$ \\
\hline Dev & & $\begin{array}{l}-0.4927 \\
{[-0.522]}\end{array}$ & & $\begin{array}{l}-0.4546 \\
{[-0.460]}\end{array}$ & & $\begin{array}{l}0.2696 \\
{[0.501]}\end{array}$ & & $\begin{array}{c}0.2080 \\
{[0.368]}\end{array}$ \\
\hline Dev*Spprt & & $\begin{array}{l}0.1650 \\
{[0.806]}\end{array}$ & & $\begin{array}{l}0.1509 \\
{[0.669]}\end{array}$ & & $\begin{array}{l}-0.1625 \\
{[-1.236]}\end{array}$ & & $\begin{array}{l}-0.1586 \\
{[-1.131]}\end{array}$ \\
\hline Parent & & & $\begin{array}{c}-2.1273 * * * \\
{[-4.747]}\end{array}$ & $\begin{array}{c}-1.7560 * * * \\
{[-3.651]}\end{array}$ & & & $\begin{array}{l}-0.8011 \\
{[-1.115]}\end{array}$ & $\begin{array}{l}-1.0445 \\
{[-1.281]}\end{array}$ \\
\hline Parent*Spprt & & & $\begin{array}{c}0.5580 * * * \\
{[4.561]}\end{array}$ & $\begin{array}{c}0.4890 * * * \\
{[3.860]}\end{array}$ & & & $\begin{array}{l}0.2050 \\
{[1.189]}\end{array}$ & $\begin{array}{l}0.2576 \\
{[1.414]}\end{array}$ \\
\hline Dev*Parent*Spprt & & & & $\begin{array}{l}-0.0413 \\
{[-0.434]}\end{array}$ & & & & $\begin{array}{c}0.0210 \\
{[0.260]}\end{array}$ \\
\hline cut 1 & $\begin{array}{c}4.6655^{* * *} * \\
{[6.650]}\end{array}$ & $\begin{array}{c}4.7707 * * * \\
{[3.512]}\end{array}$ & $\begin{array}{c}4.7625^{* * *} \\
{[6.739]}\end{array}$ & $\begin{array}{c}4.8753^{* * *} * \\
{[3.570]}\end{array}$ & $\begin{array}{c}5.6843 * * * \\
{[9.807]}\end{array}$ & $\begin{array}{c}5.6716^{* * *} \\
{[7.589]}\end{array}$ & $\begin{array}{c}5.6321 * * * \\
{[9.628]}\end{array}$ & $\begin{array}{c}5.5295^{* * * *} \\
{[7.028]}\end{array}$ \\
\hline cut2 & $\begin{array}{c}5.4136^{* * *} \\
{[8.749]}\end{array}$ & $\begin{array}{c}5.5330^{* * *} \\
{[4.808]}\end{array}$ & $\begin{array}{c}5.4834 * * * \\
{[8.608]}\end{array}$ & $\begin{array}{c}5.6176^{* * *} \\
{[4.840]}\end{array}$ & $\begin{array}{c}6.3593 * * * \\
{[11.725]}\end{array}$ & $\begin{array}{c}6.2773 * * * \\
{[8.751]}\end{array}$ & $\begin{array}{c}6.3004 * * * \\
{[11.606]}\end{array}$ & $\begin{array}{c}6.1281 * * * \\
{[8.239]}\end{array}$ \\
\hline cut3 & $\begin{array}{c}6.1755^{* * *} \\
{[9.757]}\end{array}$ & $\begin{array}{c}6.3970 * * * \\
{[6.183]}\end{array}$ & $\begin{array}{c}6.1734 * * * \\
{[9.407]}\end{array}$ & $\begin{array}{c}6.4024 * * * \\
{[6.064]}\end{array}$ & $\begin{array}{c}6.8729 * * * \\
{[13.456]}\end{array}$ & $\begin{array}{c}6.7930 * * * \\
{[10.160]}\end{array}$ & $\begin{array}{c}6.8159 * * * \\
{[13.185]}\end{array}$ & $\begin{array}{c}6.6467 * * * \\
{[9.442]}\end{array}$ \\
\hline cut4 & $\begin{array}{c}7.1998 * * * \\
{[10.391]}\end{array}$ & $\begin{array}{c}7.5817 * * * \\
{[7.469]}\end{array}$ & $\begin{array}{c}7.1613 * * * \\
{[10.057]}\end{array}$ & $\begin{array}{c}7.5450^{* * *} \\
{[7.299]}\end{array}$ & $\begin{array}{c}7.2714 * * * \\
{[13.533]}\end{array}$ & $\begin{array}{c}7.1926^{* * *} \\
{[10.627]}\end{array}$ & $\begin{array}{c}7.2102 * * * \\
{[13.187]}\end{array}$ & $\begin{array}{c}7.0411^{* * *} \\
{[9.792]}\end{array}$ \\
\hline cut5 & $\begin{array}{c}8.2031 * * * \\
{[10.984]}\end{array}$ & $\begin{array}{c}8.5320 * * * \\
{[8.405]}\end{array}$ & $\begin{array}{c}8.2104 * * * \\
{[10.656]}\end{array}$ & $\begin{array}{c}8.5325 * * * \\
{[8.328]}\end{array}$ & $\begin{array}{c}8.0943 * * * \\
{[14.141]}\end{array}$ & $\begin{array}{c}7.8834 * * * \\
{[11.679]}\end{array}$ & $\begin{array}{c}8.0308 * * * \\
{[13.760]}\end{array}$ & $\begin{array}{c}7.7322 * * * \\
{[10.811]}\end{array}$ \\
\hline cut6 & $\begin{array}{c}8.5294 * * * \\
{[10.979]}\end{array}$ & $\begin{array}{c}8.9505^{* * *} \\
{[8.814]}\end{array}$ & $\begin{array}{c}8.5676^{* * *} \\
{[10.632]}\end{array}$ & $\begin{array}{c}8.9719^{* * *} \\
{[8.778]}\end{array}$ & $\begin{array}{c}8.8013 * * * \\
{[14.413]}\end{array}$ & $\begin{array}{c}8.5563 * * * \\
{[12.488]}\end{array}$ & $\begin{array}{c}8.7422^{* * *} \\
{[14.091]}\end{array}$ & $\begin{array}{c}8.4172 * * * \\
{[11.702]}\end{array}$ \\
\hline cut7 & $\begin{array}{c}9.3231 * * * \\
{[11.031]}\end{array}$ & $\begin{array}{c}9.9089^{* * *} \\
{[9.526]}\end{array}$ & $\begin{array}{c}9.4142 * * * \\
{[10.710]}\end{array}$ & $\begin{array}{c}9.9697 * * * \\
{[9.516]}\end{array}$ & $\begin{array}{c}9.8333 * * * \\
{[14.907]}\end{array}$ & $\begin{array}{c}9.6083 * * * \\
{[13.489]}\end{array}$ & $\begin{array}{c}9.7836 * * * \\
{[14.631]}\end{array}$ & $\begin{array}{c}9.4896 * * * \\
{[12.764]}\end{array}$ \\
\hline cut8 & $\begin{array}{c}10.1391 * * * \\
{[11.288]}\end{array}$ & $\begin{array}{c}10.7166^{* * * *} \\
{[9.978]}\end{array}$ & $\begin{array}{c}10.2606^{* * *} \\
{[10.988]}\end{array}$ & $\begin{array}{c}10.8011^{* * *} \\
{[9.997]}\end{array}$ & $\begin{array}{c}10.7780^{* * * *} \\
{[15.325]}\end{array}$ & $\begin{array}{c}10.5555^{* * * *} \\
{[13.950]}\end{array}$ & $\begin{array}{c}10.7381^{* * *} \\
{[15.083]}\end{array}$ & $\begin{array}{c}10.4484 * * * \\
{[13.275]}\end{array}$ \\
\hline cut 9 & $\begin{array}{c}10.8961 * * * \\
{[11.644]}\end{array}$ & $\begin{array}{c}11.4522 * * * \\
{[10.473]}\end{array}$ & $\begin{array}{c}11.0602 * * * \\
{[11.368]}\end{array}$ & $\begin{array}{c}11.5714 * * * \\
{[10.534]}\end{array}$ & $\begin{array}{c}11.4422 * * * \\
{[15.650]}\end{array}$ & $\begin{array}{c}11.1589 * * * \\
{[14.374]}\end{array}$ & $\begin{array}{c}11.4074 * * * \\
{[15.430]}\end{array}$ & $\begin{array}{c}11.0568 * * * \\
{[13.724]}\end{array}$ \\
\hline cut 10 & $\begin{array}{c}11.7658 * * * \\
{[11.847]}\end{array}$ & $\begin{array}{c}12.3834 * * * \\
{[10.891]}\end{array}$ & $\begin{array}{c}11.9885^{* * * *} \\
{[11.602]}\end{array}$ & $\begin{array}{c}12.5546 * * * \\
{[10.990]}\end{array}$ & $\begin{array}{c}12.3016^{* * * *} \\
{[16.063]}\end{array}$ & $\begin{array}{c}12.0626 * * * \\
{[14.690]}\end{array}$ & $\begin{array}{c}12.2756^{* * * *} \\
{[15.850]}\end{array}$ & $\begin{array}{c}11.9714 * * * \\
{[14.052]}\end{array}$ \\
\hline cut11 & $\begin{array}{c}12.3790 * * * \\
{[11.936]}\end{array}$ & $\begin{array}{c}13.0049 * * * \\
{[11.075]}\end{array}$ & $\begin{array}{c}12.6249 * * * \\
{[11.695]}\end{array}$ & $\begin{array}{c}13.1964^{* * *} \\
{[11.155]}\end{array}$ & $\begin{array}{c}13.0196^{* * *} \\
{[16.389]}\end{array}$ & $\begin{array}{c}12.7872 * * * \\
{[15.001]}\end{array}$ & $\begin{array}{c}12.9951^{* * *} \\
{[16.192]}\end{array}$ & $\begin{array}{c}12.6967^{* * * *} \\
{[14.373]}\end{array}$ \\
\hline cut 12 & $\begin{array}{c}13.1025 * * * \\
{[12.198]}\end{array}$ & $\begin{array}{c}13.7542 * * * \\
{[11.409]}\end{array}$ & $\begin{array}{c}13.3604 * * * \\
{[11.938]}\end{array}$ & $\begin{array}{c}13.9577 * * * \\
{[11.464]}\end{array}$ & $\begin{array}{c}13.9580 * * * \\
{[16.627]}\end{array}$ & $\begin{array}{c}13.7342 * * * \\
{[15.089]}\end{array}$ & $\begin{array}{c}13.9300 * * * \\
{[16.425]}\end{array}$ & $\begin{array}{c}13.6375 * * * \\
{[14.484]}\end{array}$ \\
\hline cut 13 & $\begin{array}{c}14.2294 * * * \\
{[12.376]}\end{array}$ & $\begin{array}{c}14.9596 * * * \\
{[11.927]}\end{array}$ & $\begin{array}{c}14.5063^{* * *} \\
{[12.098]}\end{array}$ & $\begin{array}{c}15.1814^{* * *} \\
{[11.912]}\end{array}$ & $\begin{array}{c}15.6972 * * * \\
{[15.714]}\end{array}$ & $\begin{array}{c}15.4993 * * * \\
{[14.178]}\end{array}$ & $\begin{array}{c}15.6591 * * * \\
{[15.616]}\end{array}$ & $\begin{array}{c}15.3870 * * * \\
{[13.756]}\end{array}$ \\
\hline cut 14 & $\begin{array}{c}15.1437 * * * \\
{[11.701]}\end{array}$ & $\begin{array}{c}16.1091 * * * \\
{[12.068]}\end{array}$ & $\begin{array}{c}15.4480^{* * *} \\
{[11.425]}\end{array}$ & $\begin{array}{c}16.3680^{* * *} \\
{[11.990]}\end{array}$ & $\begin{array}{c}16.6779 * * * \\
{[15.601]}\end{array}$ & $\begin{array}{c}16.4863 * * * \\
{[14.365]}\end{array}$ & $\begin{array}{c}16.6339 * * * \\
{[15.497]}\end{array}$ & $\begin{array}{c}16.3665^{* * * *} \\
{[13.941]}\end{array}$ \\
\hline cut 15 & $\begin{array}{c}16.5383 * * * \\
{[12.193]} \\
\end{array}$ & $\begin{array}{c}17.3918 * * * \\
{[12.179]} \\
\end{array}$ & $\begin{array}{c}16.8275^{* * *} \\
{[11.914]} \\
\end{array}$ & $\begin{array}{c}17.6299 * * * \\
{[12.100]} \\
\end{array}$ & $\begin{array}{c}16.9420^{* * * *} \\
{[14.761]}\end{array}$ & $\begin{array}{c}16.7507 * * * \\
{[13.736]} \\
\end{array}$ & $\begin{array}{c}16.8937 * * * \\
{[14.696]}\end{array}$ & $\begin{array}{c}16.6259 * * * \\
{[13.392]} \\
\end{array}$ \\
\hline Observations & 297 & 283 & 297 & & 324 & 304 & 324 & 304 \\
\hline Wald Chi2 & 156.4 & 214.4 & 156.1 & 207.4 & 304.3 & 295.7 & 320.7 & 311.0 \\
\hline Prob $>$ Chi2 & 0 & 0 & 0 & 0 & 0 & 0 & 0 & 0 \\
\hline Pseudo R2 & 0.346 & 0.366 & 0.358 & 0.376 & 0.355 & 0.355 & 0.357 & 0.357 \\
\hline
\end{tabular}


Table 7. Using Firm Balance Sheet Information for Listed Firms

\begin{tabular}{|c|c|c|c|c|c|c|c|c|}
\hline & \multicolumn{4}{|c|}{ end-2007 } & \multicolumn{4}{|c|}{ end-2009 } \\
\hline & $(1)$ & $(2)$ & (3) & (4) & $(5)$ & (6) & $(7)$ & $(8)$ \\
\hline RoA & $\begin{array}{c}0.1453 * * * \\
{[2.949]}\end{array}$ & $\begin{array}{c}0.1893 * * * \\
{[3.960]}\end{array}$ & $\begin{array}{c}0.1405 * * * \\
{[2.815]}\end{array}$ & $\begin{array}{c}0.1927 * * * \\
{[3.885]}\end{array}$ & $\begin{array}{c}0.3589 * * * \\
{[4.516]}\end{array}$ & $\begin{array}{c}0.3793 * * * \\
{[4.467]}\end{array}$ & $\begin{array}{c}0.3664 * * * \\
{[4.560]}\end{array}$ & $\begin{array}{c}0.3948 * * * \\
{[4.576]}\end{array}$ \\
\hline $\mathrm{D} / \mathrm{A}$ & $\begin{array}{l}-0.0044 \\
{[-0.995]}\end{array}$ & $\begin{array}{l}-0.0062 \\
{[-1.266]}\end{array}$ & $\begin{array}{l}-0.0042 \\
{[-0.921]}\end{array}$ & $\begin{array}{l}-0.0058 \\
{[-1.154]}\end{array}$ & $\begin{array}{l}-0.0003 \\
{[-0.059]}\end{array}$ & $\begin{array}{l}-0.0005 \\
{[-0.098]}\end{array}$ & $\begin{array}{l}-0.0001 \\
{[-0.018]}\end{array}$ & $\begin{array}{l}-0.0001 \\
{[-0.015]}\end{array}$ \\
\hline TA/GDP & $\begin{array}{c}0.5891 * * * \\
{[3.150]}\end{array}$ & $\begin{array}{c}0.7020 * * * \\
{[3.635]}\end{array}$ & $\begin{array}{c}0.6102 * * * \\
{[2.763]}\end{array}$ & $\begin{array}{c}0.7281 * * * \\
{[3.150]}\end{array}$ & $\begin{array}{c}0.4622 * * \\
{[2.032]}\end{array}$ & $\begin{array}{c}0.4993 * * \\
{[2.214]}\end{array}$ & $\begin{array}{c}0.4845 * * \\
{[2.081]}\end{array}$ & $\begin{array}{c}0.5317 * * \\
{[2.331]}\end{array}$ \\
\hline Spprt & $\begin{array}{c}0.4715 * * * \\
{[7.393]}\end{array}$ & $\begin{array}{c}0.4294 * * * \\
{[6.121]}\end{array}$ & $\begin{array}{c}0.4393 * * * \\
{[6.597]}\end{array}$ & $\begin{array}{c}0.3944 * * * \\
{[5.281]}\end{array}$ & $\begin{array}{c}0.5523 * * * \\
{[9.102]}\end{array}$ & $\begin{array}{c}0.5175^{* * *} * \\
{[7.591]}\end{array}$ & $\begin{array}{c}0.5406 * * * \\
{[8.424]}\end{array}$ & $\begin{array}{c}0.4960 * * * \\
{[6.946]}\end{array}$ \\
\hline Svrgn & $\begin{array}{c}0.3530 * * * \\
{[12.912]}\end{array}$ & $\begin{array}{c}0.3159 * * * \\
{[7.914]}\end{array}$ & $\begin{array}{c}0.3477 * * * \\
{[12.619]}\end{array}$ & $\begin{array}{c}0.3076 * * * \\
{[7.629]}\end{array}$ & $\begin{array}{c}0.3576 * * * \\
{[12.322]}\end{array}$ & $\begin{array}{c}0.3145 * * * \\
{[8.962]}\end{array}$ & $\begin{array}{c}0.3559 * * * \\
{[12.162]}\end{array}$ & $\begin{array}{c}0.3075^{* * *} * \\
{[8.854]}\end{array}$ \\
\hline Dev & & $\begin{array}{c}-2.1776^{* *} \\
{[-2.313]}\end{array}$ & & $\begin{array}{c}-2.3090 * * \\
{[-2.261]}\end{array}$ & & $\begin{array}{l}-0.9205 \\
{[-1.453]}\end{array}$ & & $\begin{array}{c}-1.1461 * \\
{[-1.785]}\end{array}$ \\
\hline Dev*Spprt & & $\begin{array}{c}0.5378 * * \\
{[2.539]}\end{array}$ & & $\begin{array}{c}0.5857 * * \\
{[2.463]}\end{array}$ & & $\begin{array}{l}0.1593 \\
{[1.031]}\end{array}$ & & $\begin{array}{c}0.2242 \\
{[1.402]}\end{array}$ \\
\hline Parent & & & $\begin{array}{c}-0.8438 * * \\
{[-2.056]}\end{array}$ & $\begin{array}{l}-0.4947 \\
{[-0.869]}\end{array}$ & & & $\begin{array}{l}-1.0065 \\
{[-1.520]}\end{array}$ & $\begin{array}{l}-1.0733 \\
{[-1.301]}\end{array}$ \\
\hline Parent*Spprt & & & $\begin{array}{c}0.2472 * * \\
{[2.169]}\end{array}$ & $\begin{array}{c}0.1812 \\
{[1.351]}\end{array}$ & & & $\begin{array}{c}0.2307 \\
{[1.388]}\end{array}$ & $\begin{array}{c}0.2510 \\
{[1.372]}\end{array}$ \\
\hline Dev*Parent*Spprt & & & & $\begin{array}{l}-0.0964 \\
{[-0.974]}\end{array}$ & & & & $\begin{array}{l}-0.0509 \\
{[-0.552]}\end{array}$ \\
\hline cut1 & $\begin{array}{c}1.2503 * * * \\
{[2.907]}\end{array}$ & $\begin{array}{l}-0.1289 \\
{[-0.117]}\end{array}$ & $\begin{array}{c}1.1348 * * * \\
{[2.634]}\end{array}$ & $\begin{array}{l}-0.2898 \\
{[-0.253]}\end{array}$ & $\begin{array}{c}2.6584 * * * \\
{[5.690]}\end{array}$ & $\begin{array}{c}1.9285^{* * *} * \\
{[2.810]}\end{array}$ & $\begin{array}{c}2.6170 * * * \\
{[5.604]}\end{array}$ & $\begin{array}{c}1.7591 * * \\
{[2.564]}\end{array}$ \\
\hline cut 2 & $\begin{array}{c}1.8945 * * * \\
{[5.840]}\end{array}$ & $\begin{array}{c}0.5417 \\
{[0.619]}\end{array}$ & $\begin{array}{c}1.7646 * * * \\
{[5.264]}\end{array}$ & $\begin{array}{c}0.3689 \\
{[0.400]}\end{array}$ & $\begin{array}{c}3.1353 * * * \\
{[8.121]}\end{array}$ & $\begin{array}{c}2.3407 * * * \\
{[3.745]}\end{array}$ & $\begin{array}{c}3.0885^{* * *} * \\
{[7.916]}\end{array}$ & $\begin{array}{c}2.1695 * * * \\
{[3.472]}\end{array}$ \\
\hline cut3 & $\begin{array}{c}2.3896 * * * \\
{[7.587]}\end{array}$ & $\begin{array}{r}1.1730 \\
{[1.576]}\end{array}$ & $\begin{array}{c}2.2396 * * * \\
{[6.712]}\end{array}$ & $\begin{array}{c}0.9798 \\
{[1.231]}\end{array}$ & $\begin{array}{c}3.3489 * * * \\
{[9.529]}\end{array}$ & $\begin{array}{c}2.5674 * * * \\
{[4.433]}\end{array}$ & $\begin{array}{c}3.2973 * * * \\
{[9.192]}\end{array}$ & $\begin{array}{c}2.3946 * * * \\
{[4.143]}\end{array}$ \\
\hline cut4 & $\begin{array}{c}3.2137 * * * \\
{[9.560]}\end{array}$ & $\begin{array}{c}2.2217 * * * \\
{[3.241]}\end{array}$ & $\begin{array}{c}3.0454 * * * \\
{[8.695]}\end{array}$ & $\begin{array}{c}2.0158 * * * \\
{[2.759]}\end{array}$ & $\begin{array}{c}3.6194 * * * \\
{[9.669]}\end{array}$ & $\begin{array}{c}2.8580^{*} * * \\
{[5.107]}\end{array}$ & $\begin{array}{c}3.5597 * * * \\
{[9.315]}\end{array}$ & $\begin{array}{c}2.6815 * * * \\
{[4.799]}\end{array}$ \\
\hline cut5 & $\begin{array}{c}4.0114 * * * \\
{[11.079]}\end{array}$ & $\begin{array}{c}3.0207 * * * \\
{[4.693]}\end{array}$ & $\begin{array}{c}3.8502 * * * \\
{[10.389]}\end{array}$ & $\begin{array}{c}2.8292 * * * \\
{[4.208]}\end{array}$ & $\begin{array}{c}4.1208 * * * \\
{[10.381]}\end{array}$ & $\begin{array}{c}3.3980 * * * \\
{[6.072]}\end{array}$ & $\begin{array}{c}4.0550 * * * \\
{[10.059]}\end{array}$ & $\begin{array}{c}3.2233 * * * \\
{[5.887]}\end{array}$ \\
\hline cut6 & $\begin{array}{c}4.2486 * * * \\
{[11.168]}\end{array}$ & $\begin{array}{c}3.3672 * * * \\
{[5.276]}\end{array}$ & $\begin{array}{c}4.0907 * * * \\
{[10.537]}\end{array}$ & $\begin{array}{c}3.1833 * * * \\
{[4.832]}\end{array}$ & $\begin{array}{c}4.6721^{* * *} \\
{[11.145]}\end{array}$ & $\begin{array}{c}3.9283^{* * *} \\
{[7.119]}\end{array}$ & $\begin{array}{c}4.6114 * * * \\
{[10.853]}\end{array}$ & $\begin{array}{c}3.7678 * * * \\
{[6.976]}\end{array}$ \\
\hline cut7 & $\begin{array}{c}4.8768 * * * \\
{[11.528]}\end{array}$ & $\begin{array}{c}4.2073 * * * \\
{[6.545]}\end{array}$ & $\begin{array}{c}4.7246 * * * \\
{[10.983]}\end{array}$ & $\begin{array}{c}4.0338 * * * \\
{[6.154]}\end{array}$ & $\begin{array}{c}5.4787 * * * \\
{[12.185]}\end{array}$ & $\begin{array}{c}4.7641 * * * \\
{[8.320]}\end{array}$ & $\begin{array}{c}5.4259^{* * *} \\
{[11.938]}\end{array}$ & $\begin{array}{c}4.6185 * * * \\
{[8.195]}\end{array}$ \\
\hline cut8 & $\begin{array}{c}5.4419 * * * \\
{[11.712]}\end{array}$ & $\begin{array}{c}4.7581 * * * \\
{[7.221]}\end{array}$ & $\begin{array}{c}5.2899 * * * \\
{[11.234]}\end{array}$ & $\begin{array}{c}4.5866^{* * *} \\
{[6.869]}\end{array}$ & $\begin{array}{c}6.1543 * * * \\
{[12.970]}\end{array}$ & $\begin{array}{c}5.4310^{* * *} \\
{[9.034]}\end{array}$ & $\begin{array}{c}6.1054 * * * \\
{[12.731]}\end{array}$ & $\begin{array}{c}5.2917 * * * \\
{[8.932]}\end{array}$ \\
\hline cut9 & $\begin{array}{c}6.0378 * * * \\
{[12.218]}\end{array}$ & $\begin{array}{c}5.3633 * * * \\
{[7.948]}\end{array}$ & $\begin{array}{c}5.8871 * * * \\
{[11.785]}\end{array}$ & $\begin{array}{c}5.1923 * * * \\
{[7.633]}\end{array}$ & $\begin{array}{c}6.6821 * * * \\
{[13.390]}\end{array}$ & $\begin{array}{c}5.9216^{* * *} \\
{[9.631]}\end{array}$ & $\begin{array}{c}6.6355^{* * *} \\
{[13.165]}\end{array}$ & $\begin{array}{c}5.7851 * * * \\
{[9.543]}\end{array}$ \\
\hline cut 10 & $\begin{array}{c}6.5886 * * * \\
{[12.605]}\end{array}$ & $\begin{array}{c}5.9557 * * * \\
{[8.582]}\end{array}$ & $\begin{array}{c}6.4449 * * * \\
{[12.220]}\end{array}$ & $\begin{array}{c}5.7888^{* * *} \\
{[8.299]}\end{array}$ & $\begin{array}{c}7.3772 * * * \\
{[13.725]}\end{array}$ & $\begin{array}{c}6.6291 * * * \\
{[10.208]}\end{array}$ & $\begin{array}{c}7.3357 * * * \\
{[13.519]}\end{array}$ & $\begin{array}{c}6.4962 * * * \\
{[10.111]}\end{array}$ \\
\hline cut11 & $\begin{array}{c}7.0716^{* * *} \\
{[13.047]}\end{array}$ & $\begin{array}{c}6.4366 * * * \\
{[9.145]}\end{array}$ & $\begin{array}{c}6.9354 * * * \\
{[12.693]}\end{array}$ & $\begin{array}{c}6.2743 * * * \\
{[8.872]}\end{array}$ & $\begin{array}{c}8.0350 * * * \\
{[14.054]}\end{array}$ & $\begin{array}{c}7.2814 * * * \\
{[10.780]}\end{array}$ & $\begin{array}{c}7.9976^{* * *} \\
{[13.874]}\end{array}$ & $\begin{array}{c}7.1500 * * * \\
{[10.691]}\end{array}$ \\
\hline cut 12 & $\begin{array}{c}7.6400 * * * \\
{[13.253]}\end{array}$ & $\begin{array}{c}7.0129 * * * \\
{[9.605]}\end{array}$ & $\begin{array}{c}7.5098 * * * \\
{[12.936]}\end{array}$ & $\begin{array}{c}6.8540 * * * \\
{[9.359]}\end{array}$ & $\begin{array}{c}8.7876 * * * \\
{[14.207]}\end{array}$ & $\begin{array}{c}8.0193 * * * \\
{[11.171]}\end{array}$ & $\begin{array}{c}8.7517 * * * \\
{[14.028]}\end{array}$ & $\begin{array}{c}7.8862 * * * \\
{[11.090]}\end{array}$ \\
\hline cut 13 & $\begin{array}{c}8.6028 * * * \\
{[13.193]}\end{array}$ & $\begin{array}{c}8.0065^{* * *} * \\
{[10.198]}\end{array}$ & $\begin{array}{c}8.4814 * * * \\
{[12.916]}\end{array}$ & $\begin{array}{c}7.8536^{* * *} \\
{[9.943]}\end{array}$ & $\begin{array}{c}10.1237 * * * \\
{[15.350]}\end{array}$ & $\begin{array}{c}9.3320 * * * \\
{[12.357]}\end{array}$ & $\begin{array}{c}10.0900 * * * \\
{[15.160]}\end{array}$ & $\begin{array}{c}9.1963 * * * \\
{[12.274]}\end{array}$ \\
\hline cut14 & $\begin{array}{c}9.4545 * * * \\
{[12.251]}\end{array}$ & $\begin{array}{c}9.0626 * * * \\
{[10.351]}\end{array}$ & $\begin{array}{c}9.3545 * * * \\
{[11.921]}\end{array}$ & $\begin{array}{c}8.9419 * * * \\
{[10.052]}\end{array}$ & & & & \\
\hline
\end{tabular}

cut15

\begin{tabular}{lcccccccc}
\hline Observations & 263 & 250 & 263 & 250 & 264 & 255 & 264 & 255 \\
Wald Chi2 & 178.9 & 174.8 & 174.4 & 170.4 & 218.8 & 219.3 & 217.1 & 215.0 \\
Prob $>$ Chi2 & 0 & 0 & 0 & 0 & 0 & 0 & 0 & 0 \\
Pseudo R2 & 0.250 & 0.277 & 0.253 & 0.280 & 0.251 & 0.250 & 0.253 & 0.252 \\
\hline
\end{tabular}


Table 8. Summary Table: Effect of a One-Notch Government Support Increase

\begin{tabular}{cccccc} 
& \multicolumn{2}{c}{ All Countries } & & \multicolumn{2}{c}{ Advanced Countries } \\
\cline { 2 - 3 } & 2007 (column 1) & 2009 (column 5) & & 2007 (column 4) & 2009 (column 8) \\
\hline Benchmark (Table 4) & 0.90 & 1.10 & & 0.76 & 1.10 \\
Without NF (Table 5) & 0.89 & 1.23 & & 0.55 & 1.05 \\
Listed Firms (Table 6) & 0.68 & 0.93 & & 0.61 & 0.95 \\
Fundamentals (Table 7) & 0.75 & 0.89 & & 0.56 & 0.80 \\
\hline
\end{tabular}

Table 9. Summary Table: Estimated Average Government Support in Long-Term Ratings

\begin{tabular}{|c|c|c|c|c|}
\hline & \multicolumn{2}{|c|}{2007} & \multicolumn{2}{|c|}{2009} \\
\hline & $\begin{array}{c}\text { Benchmark } \\
\text { (Table 4) }\end{array}$ & $\begin{array}{c}\text { Fundamentals } \\
\text { (Table 7) }\end{array}$ & $\begin{array}{c}\text { Benchmark } \\
\text { (Table 4) }\end{array}$ & $\begin{array}{c}\text { Fundamentals } \\
\text { (Table 7) }\end{array}$ \\
\hline Australia & 3.11 & 2.58 & 4.51 & 3.63 \\
\hline Brazil & 2.20 & 1.82 & 3.06 & 2.47 \\
\hline France & 3.97 & 3.29 & 4.79 & 3.86 \\
\hline Germany & 3.99 & 3.30 & 5.06 & 4.08 \\
\hline Greece & 3.09 & 2.56 & 3.94 & 3.17 \\
\hline Hong Kong & 3.35 & 2.78 & 4.25 & 3.42 \\
\hline Ireland & 3.72 & 3.08 & 5.24 & 4.22 \\
\hline Italy & 3.15 & 2.61 & 4.03 & 3.24 \\
\hline Japan & 3.47 & 2.88 & 4.25 & 3.42 \\
\hline Netherlands & 3.09 & 2.56 & 4.41 & 3.55 \\
\hline Portugal & 3.51 & 2.91 & 4.21 & 3.39 \\
\hline Spain & 2.97 & 2.46 & 3.62 & 2.92 \\
\hline Switzerland & 3.15 & 2.61 & 3.86 & 3.11 \\
\hline Turkey & 2.21 & 1.83 & 3.25 & 2.62 \\
\hline United Kingdom & 3.31 & 2.75 & 4.13 & 3.32 \\
\hline United States & 1.78 & 1.47 & 2.39 & 1.93 \\
\hline (U.S.top 45) & 2.88 & 2.39 & 4.51 & 3.63 \\
\hline Average & 3.11 & 2.58 & 4.09 & 3.29 \\
\hline (Using U.S. top 45) & 3.20 & 2.65 & 4.19 & 3.38 \\
\hline
\end{tabular}

Note: Coefficients, without distinguishing advanced and developing countries, are used (All Countries columns in Table 8). 
Figure 1. Distribution of Support Ratings and of Support Floor Ratings (in percent)

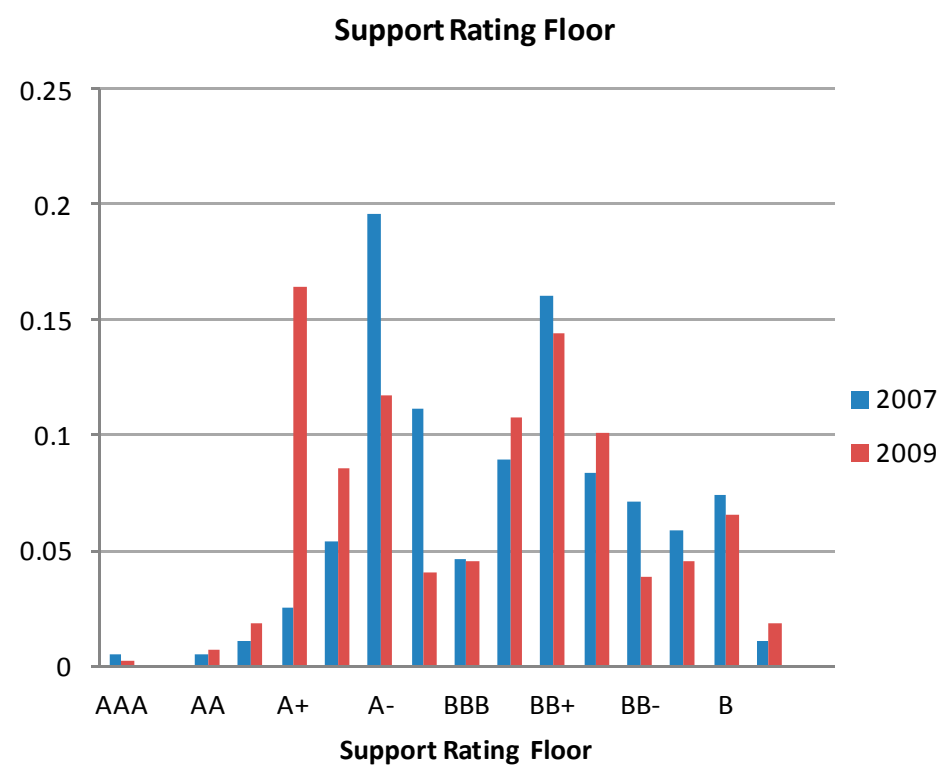

Support Rating

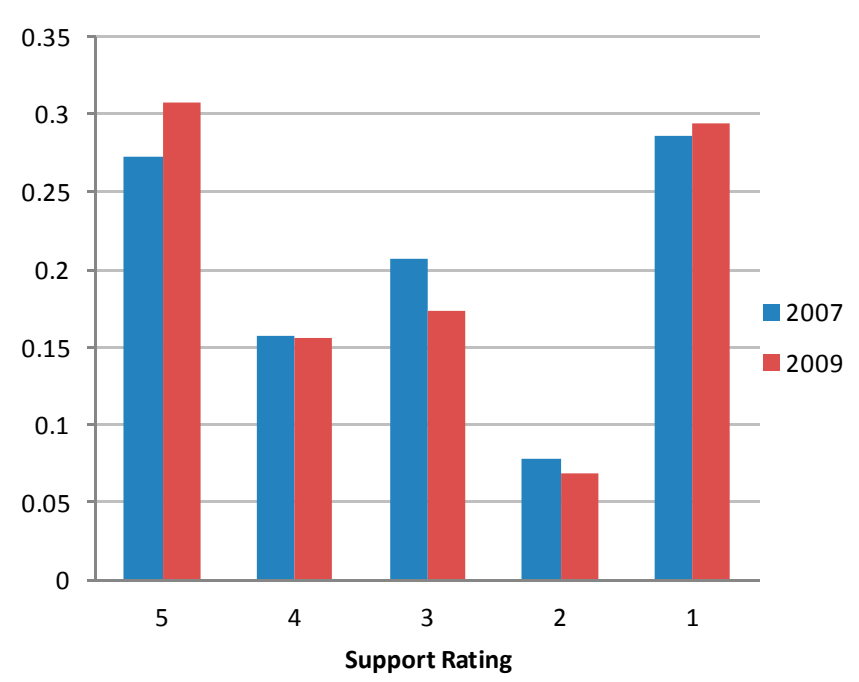

Note: Distribution does not include NF ratings. 
Figure 2. Bank Size and Support Rating Floor
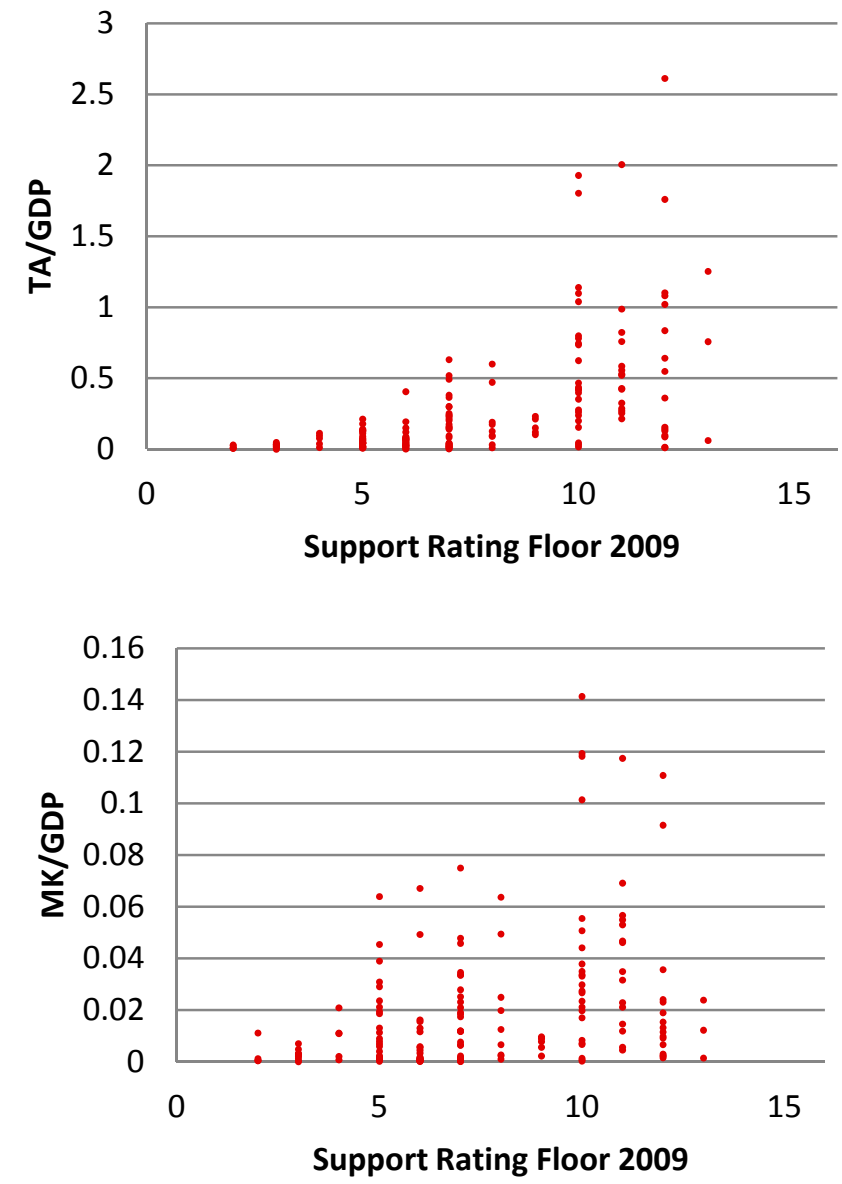

CInternational Monetary Fund. Not for Redistribution 
Figure 3. Bank Vulnerability and Support Rating Floor
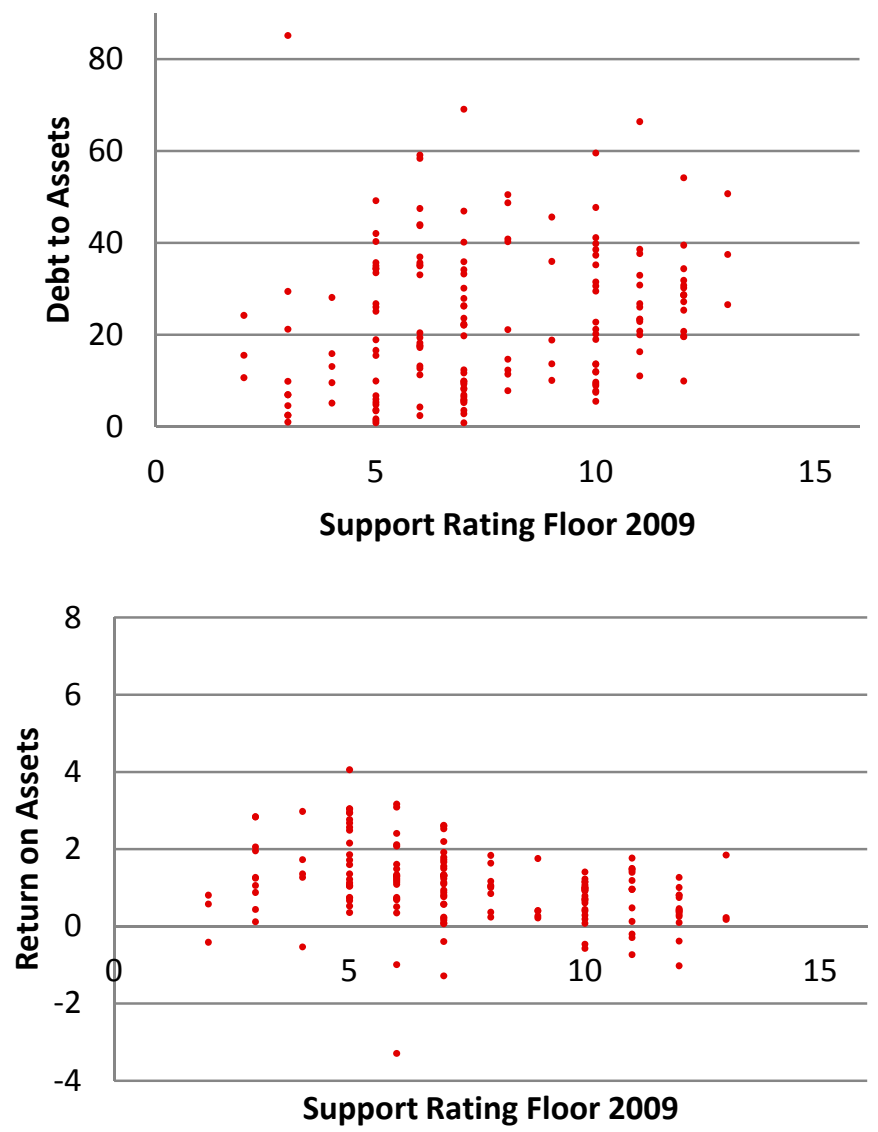

CInternational Monetary Fund. Not for Redistribution 
Appendix Table 1. Country List for the Rating Study

\begin{tabular}{|c|c|c|c|c|c|}
\hline & Freq. & Percent & & Freq. & Percent \\
\hline Albania* & 1 & 0.11 & Latvia* & 1 & 0.11 \\
\hline Andorra & 3 & 0.34 & Lithuania* & 3 & 0.34 \\
\hline Argentina* & 1 & 0.11 & Luxembourg & 2 & 0.22 \\
\hline Armenia* & 2 & 0.22 & Macao & 1 & 0.11 \\
\hline Australia & 11 & 1.23 & Macedonia* & 1 & 0.11 \\
\hline Austria & 6 & 0.67 & Malaysia* & 7 & 0.78 \\
\hline Azerbaijan* & 7 & 0.78 & Malta & 2 & 0.22 \\
\hline Bahrain & 6 & 0.67 & Mexico* & 11 & 1.23 \\
\hline Belarus* & 6 & 0.67 & Mongolia* & 2 & 0.22 \\
\hline Belgium & 4 & 0.45 & Morocco* & 1 & 0.11 \\
\hline Bermuda & 1 & 0.11 & Netherlands & 10 & 1.12 \\
\hline Bosnia \& Herzegovina* & 1 & 0.11 & New Zealand & 8 & 0.89 \\
\hline Brazil* & 18 & 2.01 & Nigeria* & 8 & 0.89 \\
\hline Bulgaria* & 7 & 0.78 & Norway & 7 & 0.78 \\
\hline Canada & 9 & 1.01 & Oman & 4 & 0.45 \\
\hline Channel Islands & 1 & 0.11 & Panama* & 6 & 0.67 \\
\hline Chile* & 4 & 0.45 & Peru* & 4 & 0.45 \\
\hline China* & 5 & 0.56 & Philippines* & 8 & 0.89 \\
\hline Colombia* & 1 & 0.11 & Poland & 7 & 0.78 \\
\hline Costa Rica* & 1 & 0.11 & Portugal & 11 & 1.23 \\
\hline Croatia & 1 & 0.11 & Puerto Rico & 1 & 0.11 \\
\hline Cyprus & 3 & 0.34 & Qatar & 5 & 0.56 \\
\hline Czech Republic & 3 & 0.34 & Romania* & 5 & 0.56 \\
\hline Denmark & 2 & 0.22 & Russia* & 47 & 5.25 \\
\hline Dominican Republic* & 3 & 0.34 & San Marino & 1 & 0.11 \\
\hline Egypt* & 2 & 0.22 & Saudi Arabia & 10 & 1.12 \\
\hline El Salvador* & 3 & 0.34 & Serbia* & 1 & 0.11 \\
\hline Finland & 3 & 0.34 & Singapore & 3 & 0.34 \\
\hline France & 23 & 2.57 & Slovakia & 2 & 0.22 \\
\hline Gabon* & 1 & 0.11 & Slovenia & 7 & 0.78 \\
\hline Georgia* & 3 & 0.34 & South Africa* & 8 & 0.89 \\
\hline Germany & 27 & 3.02 & South Korea & 11 & 1.23 \\
\hline Greece & 7 & 0.78 & Spain & 42 & 4.69 \\
\hline Guam & 1 & 0.11 & Sweden & 4 & 0.45 \\
\hline Guatemala* & 1 & 0.11 & Switzerland & 10 & 1.12 \\
\hline Hong Kong & 7 & 0.78 & Taiwan & 35 & 3.91 \\
\hline Hungary & 2 & 0.22 & Thailand* & 10 & 1.12 \\
\hline India* & 8 & 0.89 & Togo* & 1 & 0.11 \\
\hline Indonesia* & 6 & 0.67 & Trinidad \& Tobago & 2 & 0.22 \\
\hline Ireland & 8 & 0.89 & Tunisia* & 1 & 0.11 \\
\hline Israel & 2 & 0.22 & Turkey* & 20 & 2.23 \\
\hline Italy & 23 & 2.57 & Ukraine* & 8 & 0.89 \\
\hline Jamaica* & 1 & 0.11 & United Arab Emirates & 12 & 1.34 \\
\hline Japan & 28 & 3.13 & United Kingdom & 39 & 4.36 \\
\hline Jordan* & 3 & 0.34 & United States & 213 & 23.8 \\
\hline Kazakhstan* & 6 & 0.67 & Uzbekistan* & 5 & 0.56 \\
\hline Kenya* & 1 & 0.11 & Venezuela* & 7 & 0.78 \\
\hline Kuwait & 8 & 0.89 & Total & 895 & 100.00 \\
\hline
\end{tabular}

Note: * denotes developing countries $($ Dev $=1)$ where World Bank's country classifications do not classify them as "high". Taiwan is not included in the regressions with Dev variable. 


\section{Appendix Table 2. Individual Ratings and Support Ratings}

\begin{tabular}{|l|l|}
\hline Rating & Definitions Individual Ratings \\
\hline A & $\begin{array}{l}\text { A very strong bank. } \\
\text { Characteristics may include outstanding profitability and balance sheet integrity, } \\
\text { franchise, management, operating environment or prospects. }\end{array}$ \\
\hline B & $\begin{array}{l}\text { A strong bank. } \\
\text { There are no major concerns regarding the bank. Characteristics may include strong } \\
\text { profitability and balance sheet integrity, franchise, management, operating } \\
\text { environment or prospects. }\end{array}$ \\
\hline C & $\begin{array}{l}\text { An adequate bank, which, however, possesses one or more troublesome aspects. } \\
\text { There may be some concerns regarding its profitability and balance sheet integrity, } \\
\text { franchise, management, operating environment or prospects. }\end{array}$ \\
\hline D & $\begin{array}{l}\text { A bank that has weaknesses of internal and/or external origin. } \\
\text { There are concerns regarding its profitability and balance sheet integrity, franchise, } \\
\text { management, operating environment or prospects. Banks in emerging markets are } \\
\text { necessarily faced with a greater number of potential deficiencies of external origin. }\end{array}$ \\
\hline E & $\begin{array}{l}\text { A bank with very serious problems, which either requires or is likely to require } \\
\text { external support. }\end{array}$ \\
\hline F & $\begin{array}{l}\text { A bank that has either defaulted or, in Fitch Ratings' opinion, would have defaulted } \\
\text { if it had not received external support. Examples of such support include state or } \\
\text { local government support, (deposit) insurance funds, acquisition by some other } \\
\text { corporate entity or an injection of new funds from its shareholders or equivalent. }\end{array}$ \\
\hline
\end{tabular}

Gradations may be used among the ratings $\mathrm{A}$ to $\mathrm{E}$ : i.e. $\mathrm{A} / \mathrm{B}, \mathrm{B} / \mathrm{C}, \mathrm{C} / \mathrm{D}$, and $\mathrm{D} / \mathrm{E}$.

\begin{tabular}{|l|l|}
\hline Rating & Definitions Support Ratings (Numbers are flipped from the original Fitch definition) \\
\hline 5 & $\begin{array}{l}\text { A bank for which there is an extremely high probability of external support. The } \\
\text { potential provider of support is very highly rated in its own right and has a very high } \\
\text { propensity to support the bank in question. This probability of support indicates a } \\
\text { minimum Long-Term Rating floor of 'A-' }\end{array}$ \\
\hline 4 & $\begin{array}{l}\text { A bank for which there is a high probability of external support. The potential } \\
\text { provider of support is highly rated in its own right and has a high propensity to } \\
\text { provide support to the bank in question. This probability of support indicates a } \\
\text { minimum Long-Term Rating floor of 'BBB-'. }\end{array}$ \\
\hline 3 & $\begin{array}{l}\text { A bank for which there is a moderate probability of support because of uncertainties } \\
\text { about the ability or propensity of the potential provider of support to do so. This } \\
\text { probability of support indicates a minimum Long-Term Rating floor of 'BB-'. }\end{array}$ \\
\hline 2 & $\begin{array}{l}\text { A bank for which there is a limited probability of support because of significant } \\
\text { uncertainties about the ability or propensity of any possible provider of support to } \\
\text { do so. This probability of support indicates a minimum Long-Term Rating floor of } \\
\text { 'B'. }\end{array}$ \\
\hline 1 & $\begin{array}{l}\text { A bank for which there is a possibility of external support, but it cannot be relied } \\
\text { upon. This may be due to a lack of propensity to provide support or to very weak } \\
\text { financial ability to do so. This probability of support indicates a Long-Term Rating } \\
\text { floor no higher than 'B-' and in many cases, no floor at all. }\end{array}$ \\
\hline
\end{tabular}




\section{References}

Acharya, Viral V, Lasse H. Pedersen, Thomas Philippon, and Matthew Richardson, 2009, "Regulating Systemic Risk," in Viral Acharya and Matthew Richardson (eds.), Restoring Financial Stability: How to Repair a Failed System, Wiley, March.

Baker, Dean, and Travis McArthur, 2009, "The Value of the 'Too Big to Fail' Big Bank Subsidy," Issue Brief, September, Center for Economic and Policy Research (Washington).

Claessens, Stijn, Richard Herring, und Dirk Schoenmaker, 2010, "A Safer World Financial System: Improving the Resolution of Systemic Institutions," Centre for Economic Policy Research (CEPR), London.

Doluca, Hasan, Ulrich Klueh, Marco Wagner, and Beatrice Weder di Mauro, 2010, "Reducing Systemic Relevance: A Proposal," Discussion paper No 4, of the German Council of Economic Experts,

International Monetary Fund, 2010a, "A Fair and Substantial Contribution by the Financial Sector," Interim Report to G-20, March 2010.

International Monetary Fund, 2010b, United States: Publication of Financial Sector Assessment Program Documentation-Technical Note on Stress Testing, IMF Country Report No. 10/244.

Financial Stability Board, 2010a, "Reducing the Moral Hazard Posed by Systemically Important Financial Institutions," Interim report to G20 Leaders, July 2010, Basel.

— , 2010b, "G20 Leaders endorse Financial Stability Board policy framework for addressing systemically important financial institutions," Press Release, 53/2010, November 12, 2010, Basel.

Fitch, 2010, "Definition of Ratings and Other Forms of Opinion," August 2010.

Gandhi, Priyank, and Hanno Lustig, 2010, "Size Anomalies in U.S. Bank Stock Returns: A Fiscal Explanation," NBER Working Paper, No 16553.

Gray, Dale F., and Andreas A. Jobst, 2010, "Modeling Systemic and Sovereign Risks," Chapter 8 in Lessons from the Crisis, Arthur M. Berd eds., Risk books (London).

Gropp, Reint, Hendrik Hakenes, and Isabel Schnabel, 2011, "Competition, Risk Shifting and Public Bail-out Policies," Review of Financial Studies, forthcoming.

Kaplan-Appio, Idanna, 2002, "Estimating the Value of Implicit Government Guarantees to Thai Banks," Review of International Economics, Vol. 10. No. 1, pp. 26-35. 
Kocherlakota, Narayana, 2010, "Taxing Risk and the Optimal Regulation of Financial Institutions," Federal Reserve Bank of Minneapolis Economic Policy Paper, 10-3.

Moody's, 2011, “Quantifying the Value of Implicit Government Guarantees for Large Financial Institutions," Analytics Report, January.

Morgan, Donald, and Kevin Stiroh, 2005, "Too Big to Fail after All These Years," Federal Reserve Bank of New York Staff Report, No 220.

Perotti, Enrico and Javier Suarez, 2009, "Liquidity Insurance for Systemic Crises," Policy Insight, No. 31.

Resti, Andrea, and Andrea Sironi, 2005, "The Basel Committee Approach To Risk-Weights And External Ratings: What Do We Learn From Bond Spreads?" Temi di discussione (Economic working papers), No 548, Bank of Italy.

Rime, Bertrand, 2005, “Do 'Too Big to Fail' Expectations Boost Large Banks Issuer Ratings?" manuscript, Swiss National Bank.

Soussa, Farouk, 2000, “Too Big to Fail: Moral Hazard and Unfair Competition?" Chapter 1 in collective volume, Financial Stability and Central Banks: Selected Issues for financial Safety Nets and Market Discipline, Bank of England (London).

Veronesi, Pietro, and Luigi Zingales, 2009, "Paulson's Gift," manuscript, University of Chicago.

Ueda, Kenichi, and Beatrice Weder di Mauro, 2010, "Too-Big-To-Fail Subsidy: Event Study," manuscript, IMF. 